\title{
Key factors for loan repayment of micro entrepreneurs in Ghana
}

\section{Daniel Agbeko}




\section{Thesis committee}

\section{Promotor}

Prof Dr S.W.F. Omta

Professor of Management Studies

Wageningen University \& Research

\section{Co-promotors}

Dr V. Blok

Associate Professor, Management Studies Group

Wageningen University \& Research

Dr G. Van der Velde

Lecturer, Management Studies Group

Wageningen University \& Research

\section{Other members}

Prof. Dr. B.M.J. van der Meulen, Wageningen University \& Research

Prof Dr W.A. Dolfsma, Loughborough University, London, UK

Dr P.T.M. Ingenbleek, Wageningen University \& Research

Dr T. Lans, Wageningen University \& Research

This research was conducted under the auspices of Wageningen School of Social Sciences (WASS). 


\title{
Key factors for loan repayment of micro entrepreneurs in Ghana
}

\author{
Daniel Agbeko
}

\author{
Thesis \\ submitted in fulfilment of requirement for the degree of doctor \\ at Wageningen University \\ by the authority of the Rector Magnificus, \\ Prof Dr A.P.J. Mol, \\ in the presence of the \\ Thesis Committee appointed by the Academic Board \\ to be defended in public \\ on Wednesday 15 November 2017 \\ at 1.30 p.m. in the Aula.
}




\section{Daniel Agbeko}

Key factors for loan repayment of micro entrepreneurs in Ghana.

97 pages

$\mathrm{PhD}$ thesis, Wageningen University, Wageningen, the Netherlands (2017)

With references and summary in English

ISBN: 978-94-6343-794-3

DOI: $10.18174 / 423306$ 


\section{Preface and Acknowledgements}

My sincere appreciation goes to Onno Omta, for his immense guidance. This gave me the opportunity to explore alternatives and showed me analysis possibilities relevant for my research.

I am grateful to Vincent Blok for his hard work in helping me drafting my proposal and getting it reviewed and accepted. I am also grateful for his assistance in getting my first paper published. Vincent also linked me to a business partner, Thomas Lans. This led to the establishment of Quente Africa, a consultancy organization in research, microfinance, entrepreneurship and agriculture.

I am grateful to Gerben Van der Velde for his great help. I appreciate his skills in statistics and his ability to quickly understand my statistics procedures, together we ran all analyses.

My thanks go to Collins Ayine Nsor and Annewies Veerman who assisted me in the data collection procedure and qualitative papers, and to MST members for their motivation, discussions, and input during my presentations. I am particularly grateful to Teunis Brand and Jilde Garst for their assistance in translating my Dutch letters and to Lisa Ploum for organising a lovely dinner for the team.

My thanks go to MST secretary Ina Versteeg and her assistant Anne Pluijmaekers for their patience in handling issues and assistance in booking flights, and supplying me with stationery, booking appointments and a whole lot more. To assistant the administrators Jonathan Boddie, who meanwhile went to another department, Liesbeth Hijwegen and Marloes Pals, I say thank you for handling all my financial issues even at short notice.

I am grateful to my friends on campus and off campus, notably Faith, Valerie, Aisha, Waliou, Alexander, Bright (the Don), King Agbesi, Collins, Carole, Stephen and Monica who have made my stay in the Netherlands a happy one. My thanks go to Mrs Maphosa and the entire congregation of Amazing Parish Wageningen, to Henry Hubert of the Life Gate Temple of the International Central Gospel Church and the entire congregation in Ghana for their prayers and spiritual support during my 4 year $\mathrm{PhD}$ trajectory.

I thank uniCredit Ghana plc. for granting me study leave without pay to enable me pursue my $\mathrm{PhD}$. I also thank uniCredit for providing me the institution's objective loan repayment database.

I would not have been able to start my $\mathrm{PhD}$ would my wife Sussie have opposed the intention to leave the family for two years. I am grateful for her understanding and help to fulfil my dream. To my lovely kids, Autin-Paul and Sybill, I thank you for your understanding and allowing Daddy to stay abroad for two years.

Daniel Agbeko, November 2017 
Abbreviations

CSR : Corporate social responsibility

MFI : Microfinance Institution

FNGO's : Financial non-governmental organisations

NGO : Non-governmental organisation 


\section{Table of contents}

Preface and Acknowledgement............................ 5

Abbreviations................................................. 6

Chapter 1 : Introduction: Microfinance debtors in developing countries

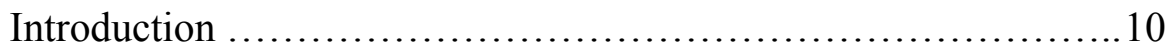

Problem statement ......................................... 14

Research questions.......................................15

Context of study: uniCredit Ghana Limited.........................16

Outline of the thesis.......................................... 17

Chapter 2: Corporate social responsibility strategies adopted by Microfinance Institutions. A case study

Introduction..................................................... 20

CSR strategies.............................................21

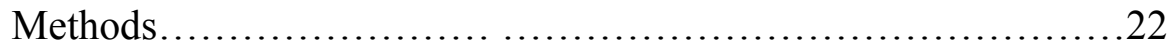

Best practices: CSR in uniCredit Ghana........................23

Conclusions and discussion................................25

Chapter 3 : Entrepreneurial and business skills and loan repayment of microfinance debtors in Ghana

Introduction...................................................... 27

Entrepreneurial and business skills.................................28

Methods....................................................... 30

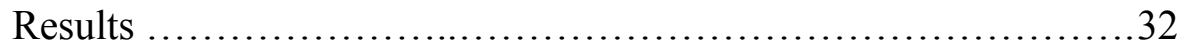

Conclusions and discussion ...................................... 36 
Chapter 4: Perception of microfinance debtors and loan officers on the relevance of entrepreneurial and business skills for loan repayment rates

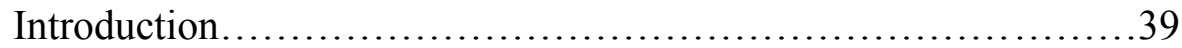

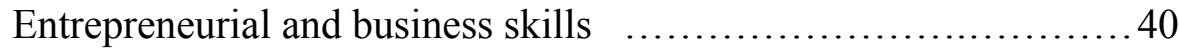

Methods........................................................41

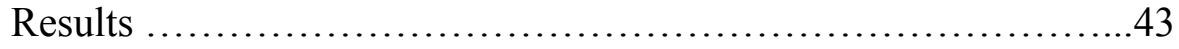

Conclusions and discussion ...................................... 46

\section{Chapter 5 : The impact of training and monitoring on loan repayment of} microfinance debtors in Ghana

Introduction.............................................. 48

Entrepreneurship training and monitoring programmes............ 49

Methods.....................................................50

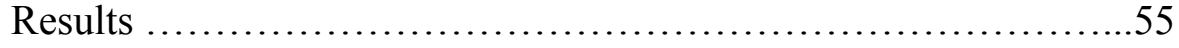

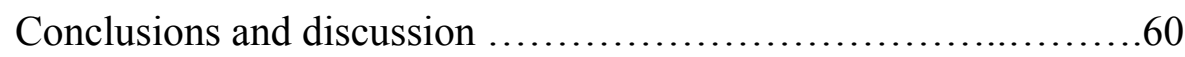

\section{Chapter 6 : Discussion and conclusions}

Introduction.....................................................

Conclusions regarding the research questions $\ldots \ldots \ldots \ldots \ldots \ldots \ldots 63$

Theoretical and methodological contributions....................65

Implications for practitioners and policy makers................67

Limitations and recommendations for further research..............68

References......................................................69

Appendix A Constructs and measurements.......................80

Appendix B Training modules...............................90

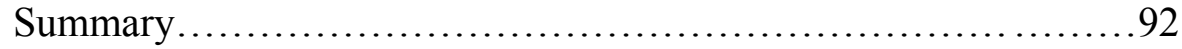

About the author........................................... 94

Training and supervision plan................................. 96 


\section{CHAPTER 1}

Introduction: Microfinance debtors in developing countries 


\section{CHAPTER 1}

\subsection{Introduction: Microfinance debtors in developing countries}

Restricted access to credit hinders entrepreneurs in developing countries to engage in new businesses and to further develop existing initiatives. This hampers economic growth (Robinson, 2002). Banks may mitigate the problem of restricted access to capital, but only do so if microbusiness entrepreneurs meet the so-called 5C-requirements for loan approval, i.e., the loan applicant should provide credit history statements, cash flow projections, character references, capital and collateral assets to secure the loans. As microbusiness entrepreneurs typically do not meet these 5C-requirements, most struggle to access credit.

Financial Non-Governmental organisations (FNGOs) may help overcome the hurdle of access to credit. These organisations provide credit without demanding the entrepreneurs to meet the 5C-requirements. FNGOs however fully depend on subsidies from developed donor countries (Bhatt and Tang, 2001; Hermes et al., 2009). Microfinance Institutions (MFIs) neither apply the 5C-criteria and, as opposed to FNGOs, do not depend on subsidies and may therefore be better able to help microbusiness entrepreneurs access credit.

Traditionally, MFIs provide for both financial services and social empowerment programmes. The package of financial and social services is referred to as Corporate social responsibility (CSR) strategies (Tang and Tang, 2012). Social services include investments in primary health care, basic literacy and occupational skills training. These investments may positively affect microfinance debtors' entrepreneurial performance and, consequently, loan repayment rates.

Among others, Cook (2001), Dumas (2001), Edgcomb (2002), Ekpe et al. (2010), Gray et al. (2011) and Karlan and Valdivia (2011) state that access to credit is necessary but not sufficient for successful entrepreneurship. Acquisition of entrepreneurial and business skills is indispensable for microbusiness success. According to Kuchar (2003), for an individual to excel in business, one needs education and work experience to acquire entrepreneurial and business skills. This thesis builds on the human capital theory (Becker 1976; Schultz 1961) to explore the benefits of knowledge and skills for microbusiness success and loan repayment rates of microfinance debtors. 
Human capital refers to the skills, abilities and knowledge of individuals (Becker, 1976). In general, it has been argued that human capital is an important source of competitive advantages for firms and nations (Dakhli and De Clercq, 2004; Gimeno et al., 1997). Human Capital theory was proposed by Schultz (1961) and developed extensively by Becker (1976). Schultz argues that both knowledge and skills are a form of capital, and that this capital is a product of deliberate investment. The concept of human capital implies an investment in people through education and training. Bruderl et al. (1992) were the first researchers to fit human capital theory in the entrepreneurial context by arguing that although the general application of human capital is on employees, there is no reason why it should not apply to entrepreneurs as well. Accordingly, entrepreneurs with higher general and specific human capital can be expected to show higher levels of performance than those with lower levels. This is termed as entrepreneurial human capital. According to Hessels and Terjesen (2008), entrepreneurial human capital refers to an individual's knowledge, skills and experiences related to entrepreneurial activity. Entrepreneurial human capital is important to entrepreneurial development. Ganotakis (2011) used the Resource Based Theory (RBT) to explain the importance of human capital to entrepreneurship. According to RBT, human capital is considered to be a source of competitive advantage for entrepreneurial firms.

\section{Human Capital and Firm Performance}

According to Ganotakis (2011), human capital can be divided into general human capital and specific human capital. General human capital for the case of the entrepreneur is usually measured by the educational qualifications and by the total number of years of working experience. Specific human capital includes specific business education, specific skills, industry related experience and managerial experience. Lefebvre and Lefebvre (2002) report that innovative and managerial capabilities of the management team are strongly associated with export performance and firm growth. Martin and Staines (2008) find that lack of managerial experience, skills and personal qualities as well as other factors such as adverse economic conditions, poorly thought out business plans and resource starvation are found as the main reasons why new firms fail. The distinguishing feature of high growth and low growth small firms is the education, training and experience of senior managers. Dhanaraj et al. (2004) evaluate managerial competencies as measured by the education of the founder, managerial experience, entrepreneurial experience, start-up experience and functional area experience versus new venture performance. The results show that relative profits tend to be high when an 
entrepreneur has more education and experience in the line of business. On the other hand, profitability tends to be low when the entrepreneur has only start up and managerial experience, but lacks an educational background. The results confirm the importance of education to new venture success. Bosma et al. (2004) also find that the endowed level of talent of a small business founder is not the unique determinant of performance. Rather, investment in industryspecific and entrepreneurship-specific human capital contributes significantly to the performance of small firm founders. The result shows that human capital appears to influence the entire set of performance measures (profitability, employment and survival). Former experience of the business founder in the industry in which he starts his business appears to improve all performance measures. Moreover, experience in activities relevant to business ownership increases the firm's survival time. Finally, high-educated people make more profits, while those who have experience as an employee create more employment. Other empirical studies, such as Hisrich and Drnovsek (2002) and Smallbone and Welter (2001), find that managerial competencies as measured by education, managerial experience, start-up experience and knowledge of the industry positively impact on the performance of new SMEs. Focusing on a developing country context, Orford et al. (2004) point out that lack of education and training have reduced management capacity in SMEs in South Africa. This is one of the reasons for the low level of entrepreneurial creation and the high failure rate of new ventures. Lack of skills, experience and knowledge are also key limiting factors for entrepreneurship in South Africa. SME owners in South Africa often lack the expertise, experience and training related to the business they establish. Because of the managerial deficiency, there is the prevalence of necessity(survivalist) compared to opportunity entrepreneurial activity in South Africa. Leitao and Franco (2008) point out that empirical research has obtained a range of results regarding this relationship between human capital and performance, but those results are not unambiguous. Empirical literature such as Appuhami (2007) find insignificant relationship between human capital and firm performance. In view of the evidence provided in the review of empirical literature, this study hypothesises that owners' human capital is positively associated with the performance of SMEs.

\section{Human capital, education and training}

Schneider et al. (2010) argue that a firm level approach is needed to better understand the relation between human capital and performance. Their empirical results indeed show that better trained employees will provide firms with more innovative output. Similarly, in the 
context of developing countries, Mahemba and Bruijn (2003) showed the importance of training for the innovative performance of firms, while Robson et al. (2009) do not find a positive relation between training and innovation in Ghana. However, most studies using human capital focus predominantly on education or years of education as a measure of human capital (Marvel and Lumpkin, 2007). We aim for a more sophisticated measure of human capital and argue that human capital within a firm does not only consists of the level of education, but also consists of firm level practices that are geared towards the development of human capital within the firm. We consider the role of practices like training as ways for lending organizations to improve the level of human capital within a debtor firm.

\section{Education}

Education refers to the level of schooling that employees of the firm possess. The level of education of employees within a firm may benefit the firm, because education enhances the ability to understand, create and process information quicker compared to individuals without education (Nelson and Phelps, 1966). Furthermore, a workforce that has a certain level of education is better able to absorb knowledge and exploit opportunities compared to a workforce without any schooling (cf. Cohen and Levinthal, 1990). Hence, we expect a positive effect of education, while the level of education of the debtor may be conducive in absorbing knowledge and transforming this knowledge into performance.

\section{Training}

We consider training as another crucial element of human capital within a firm. Training is the extra training that employees receive from the firm in order to instruct employees in specific processes and learn them specific skills and abilities. This increases the human capital of the firm by updating knowledge and capabilities of employees (Cohen and Levinthal, 1990). Furthermore, if a firm introduces a new product or service, the employees should learn new skills in order to produce these new products and services. Yet, empirical evidence is not conclusive about the role of training. For instance, Caloghirou et al. (2004) do not find a significant effect of training in developed countries, while Goedhuys (2007) does not find a significant relation between training and performance in Tanzania. However, we expect that the relation will be positive and significant in developing countries, because training of employees may compensate for the lower degree of education (Goedhuys and Srholec, 2015). 


\subsection{Problem statement}

It remains unclear whether microfinance loan clients, in the remainder of this thesis referred to as debtors, are able to use microfinance effectively. It is argued that microfinance does not mitigate the underlying problems of illiteracy, poor health and lack of savings (Bhatt and Tang, 2011). Without entrepreneurial and technical skills, people cannot make use of microfinance effectively (Epke et al., 2010; Karnami, 2007) and, therefore, are not able to alleviate their poverty (Mutisya and Masaru, 2011; Valdivia, 2011). According to the human capital theory, those who acquire knowledge and skills perform better in executing relevant tasks (Becker, 1993). Various researchers have suggested that entrepreneurial skills are positively related to entrepreneurial success (Baron and Markman, 2003; Baum et al., 2001; Baum and Locke, 2004; Chandler and Jansen, 1992; Ucbasaran et al., 2008). Also for developing countries it has been shown that improved entrepreneurial skills, knowledge and competences, acquired through entrepreneurship training, positively influence business performance and, therefore, loan repayment rates (Cook et al., 2001; Dumas, 2001; Edgcomb, 2002; Ekpe et al., 2010; Gray et al., 2011; Karlan et al., 2006). According to Echtner (1995), entrepreneurship programmes are the most effective means of reaching, educating, and significantly empowering local individuals.

It remains however unclear what set of entrepreneurial skills explains microbusiness success. Mano et al. (2011) argue that business planning skills and market orientation skills effectively improve the performance of entrepreneurs, whereas Edgcomb (2002) emphasizes the importance of financial management skills. Karlan and Valdivia (2011) argue that business planning, financial management, customer care and market orientation are the most important entrepreneurial competences. In this thesis we empirically test what set of skills explains microbusiness performance and loan repayment rates. We examine the extent to what MFI loan officers and microfinance debtors agree the relevance of various entrepreneurial and business skills and their ranking by importance.

Empirical evidence on the relevance of training programmes for microbusiness entrepreneurs in developing countries is not consistent. Karlan and Valdivia (2011) find little effect of training programmes for microbusiness performance. Lensink et al. (2011) do establish that those microfinance debtors who participate in training programmes improve on their business performances and repay their loans better. 
Most MFIs continuously monitor their debtors' business performance, provide tailored on-site business advice and help entrepreneurs access business related networks. Among others, Balogun and Alimi (1988) and Ledgerwood (1999) consider monitoring practices key to microbusiness performance and loan repayments. In this thesis we examine the impact of training and monitoring programmes on loan repayment rates.

\subsection{Research Questions}

It remains unclear whether corporate social responsibility strategies improve microbusiness performance and, therefore, microfinance debtor repayment rates. It remains unclear what set of entrepreneurial and business skills explain business performance and whether training and monitoring programmes improve loan repayment rates:

'To what extent do corporate social responsibility strategies, entrepreneurial and business skills and programmes for training and monitoring improve loan repayment rates of microfinance debtors in developing countries?'

More specifically, we examine the following research questions:

(1) To what extent do corporate social responsibility strategies improve loan repayment rates of microfinance debtors?

(2) What entrepreneurial and business skills are important for loan repayment of microfinance debtors?

(3) To what extent do microfinance debtors and MFI loan officers agree on the importance of specific entrepreneurial and business skills for loan repayment rates?

(4) What is the impact of training and monitoring programmes on loan repayment rates of microfinance debtors? 


\subsection{Context of study: uniCredit Ghana Limited}

The study site for this research is the Ghanaian Microfinance Institution uniCredit Ghana Limited, where the author of this thesis was employed from 2008 to 2015 as a manager. This allowed for access to accurate uniCredit loan repayment data. The primary focus of uniCredit is to provide financial services that are specifically tailored towards the needs of microfinance entrepreneurs and small-sized enterprises. The mission of uniCredit is to develop easily accessible financial products. As of 2011, uniCredit had twelve branches, with an institutional deposit of USD 39 million deposited by 71 thousand customers (Mix-Market, 2015). As per the end of 2016 the number of branches have increased to 17. The loans portfolio is categorized into three main sectors. The first comprises loans larger than USD 50 thousand. It accrues to 30 percent of the total uniCredit loans portfolio, and shows repayment rates above 85 percent. The second sector is the business loans sector with loans ranging from USD 4 thousand to USD 50 thousand. This sector equals 38 percent of uniCredit's total loans portfolio and shows a 77 percent repayment rate. The third sector is the microfinance sector with loans below USD 4,000. This sector constitutes 32 percent of uniCredit's total loans portfolio and shows a 45 percent repayment rate. The overall institutional loan repayment rate as of 2013 was 71 percent of the total portfolio.

Our study sites were three branches of uniCredit Ghana. These are Ashaiman, Makola and Kantamanto, located in Accra, the capital of Ghana. Ashaiman is an emerging branch, densely populated and consists primarily of petty traders. Makola is geographically close to Kantamanto and both are cosmopolitan communities. Makola is characterized by modern shops for new clothing and clothing accessories. By contrast, Kantamanto stands out for its market for second hand clothing, shoes and building materials. These three branches were singled out as research sites because these are representative for the Ghanaian context and constitute the hub of microfinance in Accra, see Figure 1.1. 
Fig. 1.1. Map of part of the Greater Accra region and the location of the three branches of uniCredit Ghana MFI.

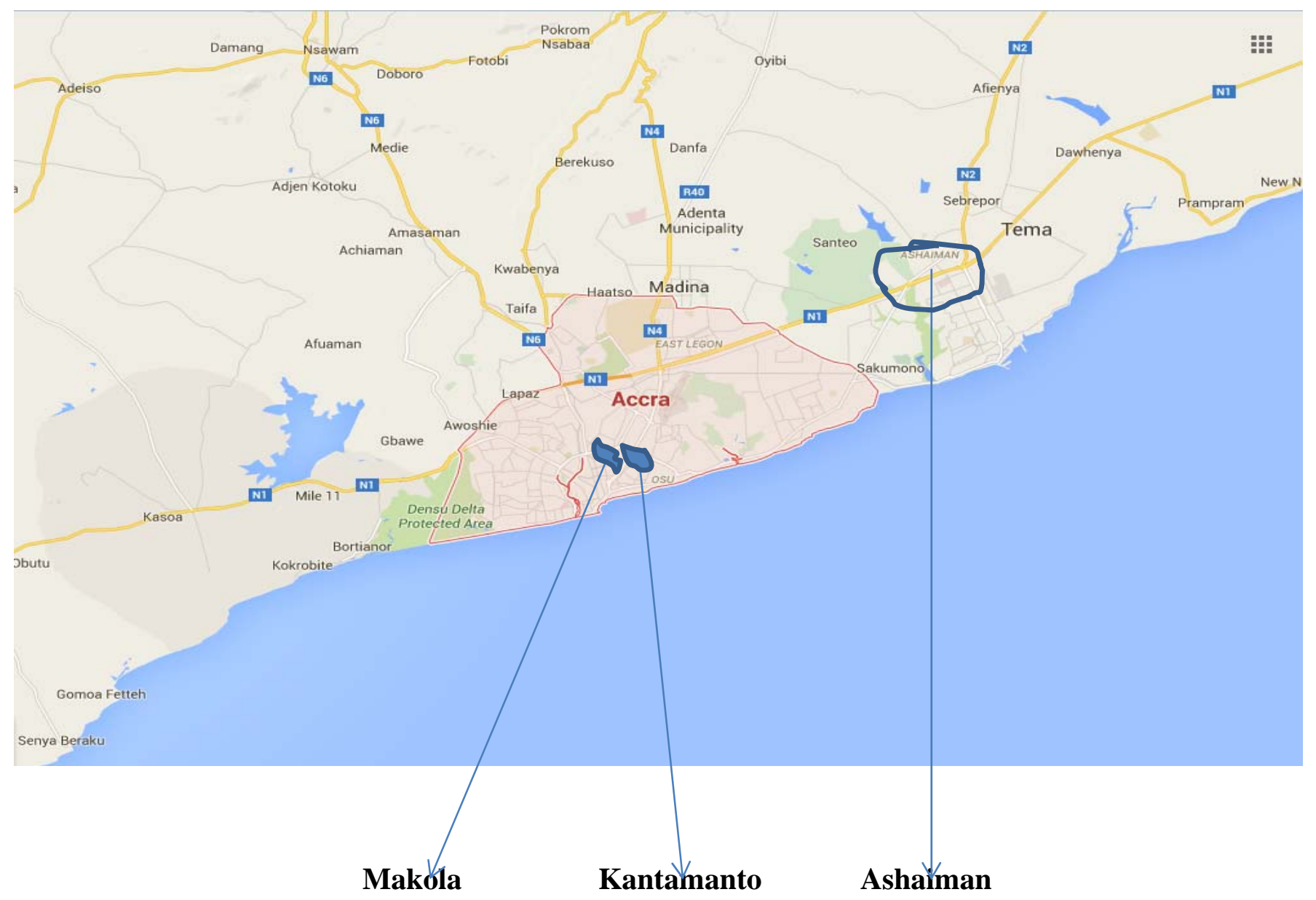

\subsection{Outline of the thesis}

Chapter 2 addresses the first research question 'To what extent do corporate social responsibility strategies improve loan repayment rates of microfinance debtors?' We argue that MFIs should consider corporate social responsibility strategies a business opportunity rather than an expense.

Chapter 3 focuses on the second research question 'What entrepreneurial and business skills are important for loan repayment of microfinance debtors?' Using objective MFI loan repayment data on 235 microfinance debtors, we empirically test whether loan repayment rates positively correlate with self-evaluations on entrepreneurial and business skills. It was established that MFI clients' self-evaluation of their entrepreneurial and business skills are not 
related to their loan repayment rates. We observe that women repay their loans better than do male microfinance debtors, and that loan repayment was also better for those entrepreneurs with more than 15 years of business experience.

Chapter 4 addresses the third research question 'To what extent do microfinance debtors and MFI loan officers agree on the importance of specific entrepreneurial and business skills for loan repayment rates?' We examine consensus within groups of debtors and loan officers with regard to the relevance of specific skills. In order to assess consensus, focus group discussions were carried out with three microfinance debtors and four loan officers of uniCredit Ghana. We do not establish consensus on the ranking of specific skills. This result suggests that every single microfinance debtor has specific needs and these should be addressed on an individual basis.

Chapter 5 discusses the fourth research question 'What is the impact of training and monitoring programmes on loan repayment rates of microfinance debtors?' In order to measure the impact of training and monitoring programmes we conducted a two-step longitudinal survey. We analyse loan repayment data on 229 microfinance debtors of uniCredit Ghana Limited. We then introduce training and monitoring interventions. After 18 months, repayment data for the same debtors are updated. The results showed that neither business nor entrepreneurial skills training programmes improve loan repayment rates. As opposed to skills training programmes, intensive monitoring does significantly improve repayment rates for all debtors, irrespective of education, business experience or gender.

Chapter 6 summarizes the results. The main findings of the thesis are reconciled with literature. The Chapter concludes with policy recommendations and suggestions for further research. 


\section{CHAPTER 2}

\section{Corporate social responsibility Strategies adopted by Microfinance Institutions. A case study}

\section{Based on:}

Agbeko, D., Blok, V., Omta, S.W.F., Van der Velde, G. (2017a). Corporate social responsibility strategies adopted by Microfinance Institutions. A case study. In S.O. Idowu and S. Vertigans (Eds.), Corporate social responsibility in challenging times (pp. 247-258). Cham, Switzerland: Springer International Publishing. 


\section{CHAPTER 2}

\section{Corporate social responsibility Strategies adopted by Microfinance Institutions. A case study}

\subsection{Introduction}

From macro-economic perspective, microbusiness are important for developing countries. As opposed to larger corporations, small local firms cannot repatriate their profits and are likely to re-invest business profits locally (Ledgerwood, 1999). More generally, many consider microbusiness entrepreneurship as a way out of unemployment and poverty (Banson, 1997).

Microfinance Institutions (MFIs) differ from traditional financial institutions in that these institutions provide microbusiness entrepreneurs packages of both financial and social empowerment programmes. The combination of financial and social empowerment programmes is known as Corporate social responsibility (CSR) strategies (Tang and Tang, 2012). Social empowerment programmes include microfinance debtor training and coaching services, health care services, sponsorships and scholarships (Cheng et al., 2014; Ribando and Bonne, 2010).

From the 1970s onwards most MFIs successfully applied CSR strategies and alleviated poverty among the poor (Yunus, 1999). From the 2008 credit crunch onwards, MFIs downsized social empowerment investments and shifted their focus from micro businesses to large and profitable corporations (Wichterich, 2012).

There is debate in the literature as to whether social empowerment programmes improve microfinance debtors' business performance and, consequently, loan repayment rates. Following Vance (1975), social empowerment programmes do not create any value for microfinance debtors. Brammer and Millington (2008) argue that social empowerment programmes may improve microfinance debtors' managerial performance, rather than business performance. Among others, Bowman and Haire (1975), Cowen et al. (1978) and Dhaliwal et al. (2011) argue that social empowerment programmes are effective and improve microfinance debtors' business performance. 
We hypothesize that the combination of financial and social empowerment programmes or CSR strategies improve microfinance debtors' business performance and loan repayment rates. We analyse the case of uniCredit Ghana MFI and examine best practices to realise the MFIs' both economic sustainability and social empowerment objectives.

In this Chapter we discuss literature on CSR strategies (Section 2). We rely on case analysis (Section 3) to examine CSR best practices (Section 4). In Section 5 we conclude that CSR strategies may improve microfinance debtors' business performance and loan repayment rates.

\subsection{CSR strategies}

The combination of financial and social empowerment programmes or CSR strategies may improve MFIs' long term sustainability. Moskowitz (1972), Parket and Eilbirt (1975) and Solomon (1985) argue that CSR strategies provide the MFI with public support. This helps raise deposits and improves funding opportunities. Elaine and Barton (1998) and Godquin (2004) observe that social empowerment investments positively affect loan repayment rates. Lensink et al. (2011) conclude that those MFIs that provide both financial and social empowerment investments show better returns on investment than do MFIs that specialize in financial services only.

Social empowerment investments do not return any short-term profits and set the socially responsible MFI at the competitive disadvantage to those MFIs that provide financial services only. Since the 2008 credit crunch, many MFI's downsized social empowerment investments and focussed on providing financial services for large and profitable corporations (Wichterich, 2012). The abandonment of CSR strategies further restricted access to capital for microbusiness entrepreneurs (Ledgerwood, 1999). Sjauw-Koen-Faa et al. (2016) observe that MFIs started demanding microfinance debtors to collateralize their merchandise. In addition, loan applicants were required to show prospective financial statements, thereby effectively cutting most of the poorly educated microbusiness entrepreneurs from access to credit.

In the CSR context MFIs typically adopted the concept of group lending. Group lending involves loans being applied for at the level of groups of debtors, rather than individual debtors. Consistent with the concept of group lending, social empowerment investments were originally 
aimed at the level of the group, rather than the individual, to further improve social cohesion. From 2008 onwards, MFIs downsized their CSR strategies and social empowerment investments were tailored to the individual entrepreneur and no longer contributed to social cohesion (Ledgerwood, 1999).

The shift from group lending to individual lending introduced the risk of adverse selection. In the absence of group level self-selection, particularly the least creditworthy entrepreneurs apply for credit. The shift from group lending to individual lending also introduced the risk of moral hazard among microfinance debtors. In the absence of group members monitoring and encouraging each other to use borrowed funds prudentially, individual debtors may use the loans for inefficient investments or expenses unrelated to their original businesses. Groups also served as social networks for exchanging business related information among entrepreneurs. Group lending therefore reduced the risks of loan defaults (Aghion et al., 2007; Armendáriz de Aghion and Morduch, 2000).

\subsection{Methods}

In our discussion on CSR best practices we rely on case analysis and examine CSR in uniCredit Ghana Limited MFI. The primary focus of uniCredit Ghana is to provide financial services tailored to the needs of micro and small-sized businesses. The mission of uniCredit is to develop easily accessible financial products (uniCredit, 2015). As of 2011, uniCredit Ghana had twelve branches in Ghana, with an institutional deposit of 40 million USD secured by 70 thousand depositors and loans portfolio worth of 24 million USD distributed among 3500 debtors (MixMarket, 2015).

In 2008 uniCredit management demanded its 12 branches to design branch level strategic plans. For our analysis, we examine the content of each of the 12 branches' strategic plan. The content of these strategic plans was coded in Atlas.ti to establish the extent to what each of the branches focused on social empowerment programmes. We then examine whether those branches that focused on social empowerment programmes showed higher loan repayment rates. 


\subsection{Best Practices: CSR in uniCredit Ghana}

We compare the 12 uniCredit Ghana MFI branches on their focus on CSR and count the use of social empowerment concepts in each of their branch level strategic plan, see Table 2.1.

Table 2.1. Focus on CSR: counts of social empowerment in each of the 122008 uniCredit Ghana MFI branch level strategic plans.

\begin{tabular}{|c|c|c|}
\hline & Branch & Frequency of 'social empowerment' \\
\hline 1. & Ashaiman & 22 \\
\hline 2. & Makola & 5 \\
\hline 3. & Kantamanto & 6 \\
\hline 4. & Kantamanto-Annex & 3 \\
\hline 5. & Apenkwa & 2 \\
\hline 6. & Domi & 0 \\
\hline 7. & Kokomlemle & 0 \\
\hline 8. & Nima & 4 \\
\hline 9. & Circle & 3 \\
\hline 10. & Ridge & 2 \\
\hline 11. & Nungua & 4 \\
\hline 12. & Kejetia- Kumasi & 2 \\
\hline
\end{tabular}

The analysis of each of the 12 strategic plans shows that uniCredit Ashaiman stands out on its focus on CSR. Relative to the other branches, its 2008 strategic plan uses the term 'social empowerment' more frequently. One quote from the Ashaiman strategic plans illustrates Ashaimans' focus on CSR: 'We believe in the human capital theory which states that 
individuals perform their businesses better if their capacity is built. We will therefore embark on intensive client training to see if the human capital theory will apply in this case'. Further analysis of the Ashaiman branch strategic plan shows that its focus on CSR enabled the Ashaiman branch to outperform the other branches in terms of deposits mobilization and loan recovery rates (73 percent for the Ashaiman branch versus 45 percent uniCredit overall microfinance repayment rate in 2013). The Ashaiman branch won the Best Branch award for 2009 and 2010. uniCredit customers have demanded for more branches to adopt CSR strategies.

High inflation and Central Bank of Ghana prime rates increase microfinance interest rates and decrease microfinance loan repayment rates (Joakim and Wismer, 2015). uniCredit Ashaiman relies on CSR strategies to reduce interest rates by mobilizing deposits. uniCredit Ashaiman's social empowerment programmes help raise uniCredit Ashaiman's deposits significantly (MixMarket, 2015).

For microfinance debtors, lack of skills may cause poor business performance. uniCredit Ashaiman organizes training programmes for its debtors on a quarterly basis. These training programmes are aimed at acquiring entrepreneurial and business skills. uniCredit Ashaiman also organizes joint outreach seminars in churches. Free and public educative talks about MFI services not only educate the attendants but also provide uniCredit Ashaiman exposure to the public.

uniCredit Ashaiman organizes quarterly debtor meeting weeks during which loan officers interact with debtors and solve their business problems. These debtor coaching weeks include a forum for debtors to discuss their challenges with uniCredit Ashaiman loan officers.

uniCredit Ashaiman provides insurances for the loans they provide, free of charge. uniCredit Ashaiman closely monitors its debtors. Loan officers regularly visit their debtors' businesses to early intervene and advise microfinance debtors if necessary. These on-site visits improve both business performance and loan repayment probabilities.

Because of health problems many debtors are unable to work and repay their loans. uniCredit Ashaiman addresses this problem by inviting officials from the hospitals to register those debtors without national health insurance. This prevents debtors from having to spend the income accrued from the business on medical expenses and to default on their loans.

Most MFIs provide inaccurate interest quotes on deposits, which jeopardizes public support for MFIs. uniCredit Ashaiman most often pays interest on fixed deposits upfront at date of purchasing the fixed deposit. This is different from many other MFIs that pay interest on fixed 
deposits on maturity date. Even though this strategy reduces the profits for uniCredit Ashaiman per deposit, the increase in number of deposits more than compensates.

\subsection{Conclusions and discussion}

The 2008 credit crunch led many MFIs to abandon their Corporate social responsibility (CSR) strategies. We examine our hypothesis that, in order to improve microfinance debtor business performance and loan repayment rates, MFIs should invest in CSR strategies.

Based on our literature review and case study of uniCredit Ghana MFI, we conclude that CSR strategies help build public support for the MFI. This helps raise deposits and improves funding opportunities. Social investments in primary health care, training and coaching of microfinance debtors, debtor meeting weeks, low-cost loan default insurances positively affect microfinance debtors' entrepreneurial performance and, consequently, loan repayment rates. We therefore argue that MFIs should consider CSR strategies a business opportunity rather than an expense. This result is consistent with Bowman and Haire (1975), Cowen et al. (1978) and Dhaliwal et al. (2011) who argue that social empowerment programmes are effective and improve microfinance debtors' business performance.

This research is based on observations for a single case study. This may limit the generalizability of results. Further research is needed to systematically compare several MFIs on the implementation of CSR strategies and to assess the significance of CSR with regards to opportunities for MFIs to raise funds and improve MFI loan repayment rates. 


\section{CHAPTER 3}

\section{Entrepreneurial and business skills and loan repayment rates of microfinance debtors in Ghana}

\section{Based on:}

Agbeko, D., Blok, V., Omta, S.W.F., Van der Velde, G. (2016). Entrepreneurial and business skills and loan repayment rates of microfinance debtors in Ghana. Journal of Developmental Entrepreneurship. Vol 21, No 4, pp. 12. DOI: 10.1142/S1084946716500242. 


\section{CHAPTER 3}

\section{Entrepreneurial and business skills and loan repayment rates of microfinance debtors in Ghana}

\subsection{Introduction}

The relevance of entrepreneurial and business skills for microfinance debtors are widely recognized (Baron and Ensley, 2006; Seuneke et al., 2013; Yunus, 1999). According to the human capital theory, those entrepreneurs endowed with skills are expected to perform better (Becker, 1993; Kraiger et al., 1993; Ployhart and Moliterno, 2011). However, literature remains unclear as to what skills really matter for business performance. For example, Mano et al. (2012) argue that planning and market orientation skills are key to business performance, whereas Edgcomb (2002) considers record keeping and break even analysis most important. Karlan and Valdivia (2011) and McKenzie and Woodruff (2013) empirically examined the impact of microfinance training programmes and established that skills training programmes fail to improve business performance.

The literature on entrepreneurial and business skills of microbusiness entrepreneurs fails to accurately assess the impact of skills on business profits or revenue (McKenzie and Woodruff, 2013). In this Chapter we relate loan repayment rates of Microfinance Institutions (MFIs) microfinance debtors to their entrepreneurial and business skills. Hence we build on the findings of Karlan and Valdivia (2011) and McKenzie and Woodruff (2013) by relating self-evaluation of entrepreneurial and business skills of microfinance debtors to objective loan repayment data. We analyse 235 Ghana MFI microfinance debtors' credit records and examine whether loan repayment rates improve for those microfinance debtors who claim to have entrepreneurial and business skills.

Section 2 reviews literature on allegedly important entrepreneurial and business skills. Section 3 discusses the methods and data. Section 4 presents the results. Section 5 concludes. 


\subsection{Entrepreneurial and business skills}

Loan repayment is critical to any MFI's long term sustainability and profitability. Loan defaults negatively affect MFI depositors and cuts access to credit for microbusiness entrepreneurs (Bastiaensen et al., 2013; Mulugetta, 2010). According to Field and Pande (2008) and Mader (2013), most MFIs in developing countries suffer from loan defaults. In 2015, the Central Bank of Ghana closed 70 MFIs mainly because of non-repayment of loans (Starfmonline, 2015). To improve loan repayment rates, most MFIs apply the 5C's criteria, i.e., the loan applicant should provide credit history statements, cash flow projections, character references, capital and collateral assets to secure the loans (Chen et al., 2009). Notwithstanding these loan application criteria, many microfinance debtors default on their loans, thereby jeopardizing the value of the MFI's loan portfolio, which may cause liquidity crises (Armendariz and Morduch, 2010; Gutierrez-Nieto et al., 2007; Ledgerwood, 1999; Ntiamoah et al., 2014).

Balogun and Alimi (1988) and Ledgerwood (1999) establish that loan defaults are caused by small loan size and poor loan monitoring. Sharma and Zeller (1997) argue that defaults result from lack of willingness among debtors to repay their loans and inadequate loan application reviews by loan officers. Olomola (2000) finds that high interest rates and delays in loan application procedures increase loan default rates. According to Bloem and Goerter (2001), loan defaults are caused by poor business decisions by the borrower and unanticipated price changes of merchandise. Kohansal and Mansoori (2009) argue that loan defaults are related to high minimum interest rates imposed by the government, monopoly power in the credit market, transaction costs incurred by borrowers and inability of the loan officers to effectively monitor the performance of their debtors. Mensah et al. (2013) also observe a negative relation between loan repayment on the one hand, and interest rates, moral hazard and over-borrowing on the other. Mensah et al. (2013) observe that the lower the interest rates, the fewer microfinance debtors divert loans into new ventures. This corresponds to Bichanga et al. (2013), who state that loan diversion is a major cause of loan defaults. Bichanga et al. (2013) also identify nonsupervision of borrowers and lagging macro-economic growth rates as causes of loan default.

In the absence of entrepreneurial and business skills one cannot expect microfinance debtors to successfully alleviate their poverty (Karlan and Valdivia, 2011) and repay their loans (Ekpe et al., 2010; Karnani, 2007; Mutisya and Yarime, 2014). Human capital theory asserts that education, work experience, upbringing by entrepreneurial parents and life experience add to 
successful entrepreneurship (Martin et al., 2013). Based on this theory, Becker (1993), Kraiger et al. (1993) and Ployhart and Moliterno (2011) postulate that individuals or groups who possess more experience, knowledge and skills perform better in executing relevant tasks.

It remains, however, unclear what set of entrepreneurial and business skills are needed for effective business performance and subsequent prompt loan repayments. According to Verhees et al. (2012) and Wiklund et al. (2009), entrepreneurial skills indispensable for microfinance debtors include willingness to take risk and innovative and pro-active behaviour. Willingness to take risk is manifest for those entrepreneurs who make strategic decisions under uncertainty (Chen et al., 1998; Oosterbeek et al., 2010; Verhees et al., 2012). Innovativeness involves the willingness to venture into new businesses, identify new markets and new methods of production (Chen et al., 1998; Verhees et al., 2012). Pro-activeness is the willingness and proficiency of microbusiness entrepreneurs to start new activities and be first to respond to new opportunities (Verhees et al., 2012). Smith and Perks (2006) and Van Dyk et al. (1992) emphasize the need to maintain customer relations and interpersonal relations. Customer relations involve customer interactions and accurate understanding of customer needs. Interpersonal relations refer to adequate employee management skills.

According to Smith and Perks (2006), business skills enable the microfinance debtor to perform better. These include general business planning, record keeping, financial management and market orientation skills. General business planning skills refer to short-term planning and budgeting skills (Smith and Perks, 2006; Van Dyk et al., 1992). Record keeping involves book keeping and inventories management (Edgcomb, 2002; Karlan and Valdivia, 2011; Mano et al., 2012; Van Dyk et al., 1992). Financial management skills include the ability to successfully raise money and design the income statement (Edgcomb, 2002; Karlan and Valdivia, 2011; Mano et al., 2012; Smith and Perks, 2006). Market orientation skills relate to business expansion, the ability to conduct market analyses and settings sales, profit and market share objectives (Alby et al., 2013; Chen et al., 1998; Edgcomb, 2002; Oosterbeek et al., 2010; OteroNeira et al., 2013; Verhees et al., 2012).

\subsection{Methods}

Whereas previous studies typically focus on the relation between entrepreneurial and business skills and business revenues and profits, see among others Karlan and Valdivia (2011) and McKenzie and Woodruff (2013), the present Chapter empirically examines the relation between 
entrepreneurial and business skills of MFI microfinance debtors and objective loan repayment data. Regarding entrepreneurial skills, we follow Smith and Perks (2006), Verhees et al. (2012) and Wiklund et al. (2009) and distinguish between customer relations (CR), risk tolerance (RT), the entrepreneurs' innovativeness (INNOV), pro-activeness (PA) and interpersonal relations (IPR). Regarding business skills, we follow Smith and Perks (2006) and distinguish between skills related to general business planning (GBP), record keeping (RK), financial management (FM) and market orientation (MO), see Figure 3.1.

Figure 3.1. Entrepreneurial skills, Business skills and Loan repayment probabilities.

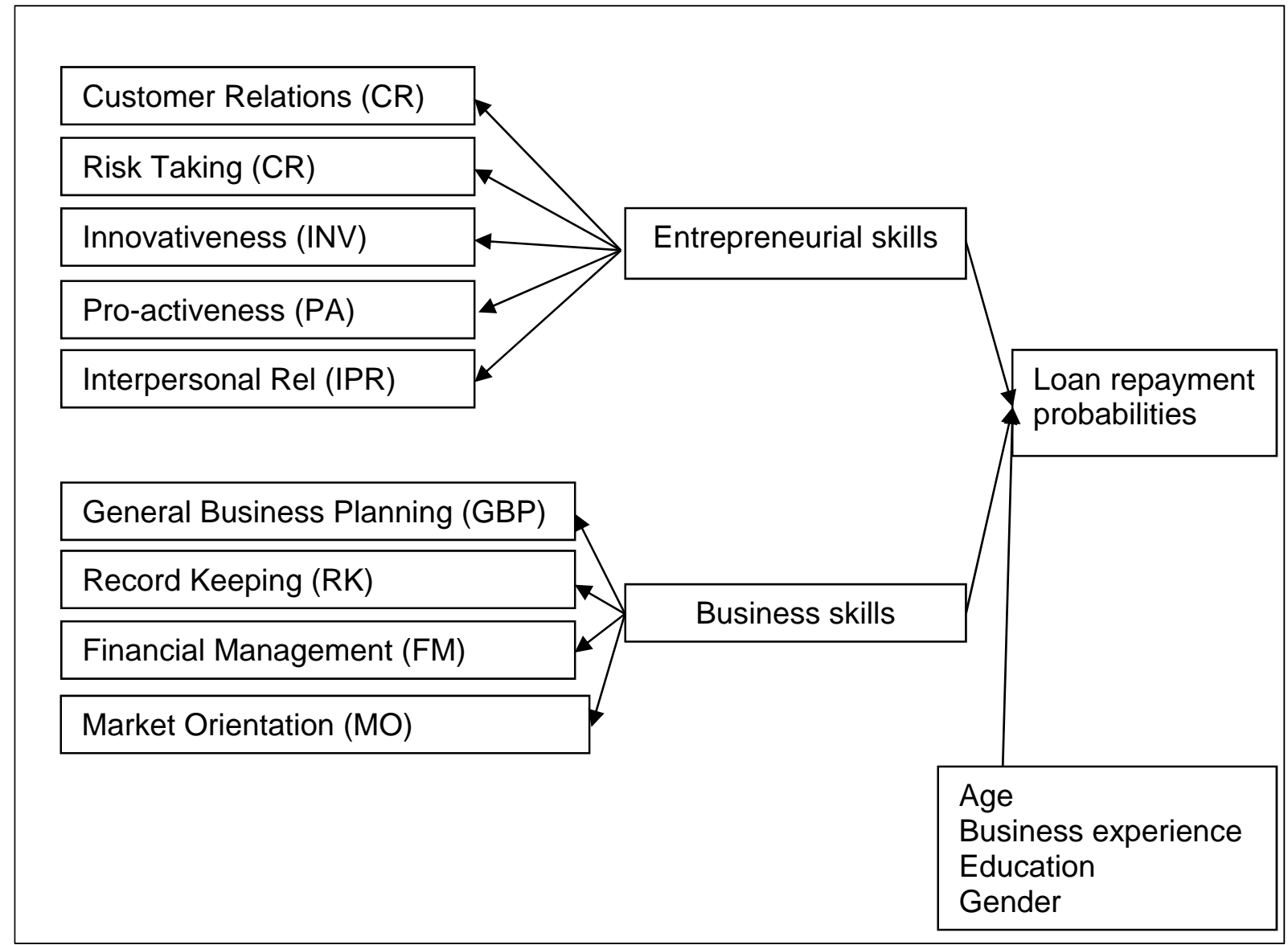

The study site for this research is a Ghanaian MFI uniCredit Ghana Limited where the author of this thesis has been employed as a manager. This allowed for access to uniCredit loan repayment data. The primary focus of uniCredit is to provide financial services specifically tailored toward the needs of microfinance debtors and SMEs. The mission of uniCredit is to develop easily accessible financial services. As of 2011, uniCredit had twelve branches, with an institutional deposit of USD 39 million deposited by 71,000 customers and a loans portfolio 
of USD 24 million with 3,500 microfinance debtors (Mix-Market, 2015). The loans portfolio is categorized into three main sectors. The first is the corporate loans sector with company loans above USD 50,000. It accrues to 30 percent of the total uniCredit loans portfolio and shows repayment rates above 85 percent. The second sector is the business loans sector with loans ranging from USD 4,000 to 50,000. This sector equals 38 percent of the loans portfolio and shows a 77 percent repayment rate. The third sector is the micro loan sector with loans below USD 4,000. This sector constitutes 32 percent of uniCredit's loans portfolio and shows a 45 percent repayment rate. Good loan repayment is defined as full repayment of principal and interest before due date, on due date, or seven days past due date.

Our study sites are three branches of uniCredit Ghana Ashaiman, Makola and Kantamanto located in Accra, the capital of Ghana. The overall repayment rate does not differ between these three branches $(p$-value $=0.40)$. Ashaiman is an emerging branch, is densely populated and primarily consists of petty traders. Makola is geographically close to Kantamanto and both are cosmopolitan communities. Makola is characterized by modern shops for new clothing and clothing accessories. By contrast, Kantamanto stands out for its market for second hand clothing, shoes and building materials. These three branches were singled out as research sites because these constitute the hub of microfinance in Accra.

To measure the entrepreneurial and business skills deemed relevant for loan repayment probabilities, questionnaires were filled out by uniCredit microfinance debtors. For the three branches, the entire loan list was downloaded and microfinance debtors with loan disbursements above USD 4,000 were excluded because these debtors cannot be considered microfinance debtors. Staff and salary workers' loans were also excluded. From the microfinance debtors loan portfolio, 235 were randomly selected from the total data on 3,277 uniCredit debtors and were included in the survey. Loan officers then invited the selected debtors to the uniCredit sites to complete the questionnaires, see Appendix A.

We use marker variable analysis to assess the severity of common method variance (CMV). We partial out CMV from the uncorrected correlations (denoted $r_{u}$ ) to arrive at CMV corrected correlation coefficients (denoted $r_{a}$ ). Testing for significance of CMV corrected correlations $\left(r_{a}\right)$ provides an estimate of the magnitude and significance of common method variance in the data. Correlations that remain significant after having controlled for CMV are unlikely to be severely 
affected by method variance (Lindell and Whitney, 2001). The CMV corrected $r_{a}$ correlations are computed as follows:

$$
r_{a}=\left(r_{u}-r_{m}\right) /\left(1-r_{m}\right)^{2}
$$

Where $r_{a}$ is the CMV corrected correlation and $r_{u}$ is the original uncorrected correlation. For $r_{u}$ we select a correlation that is expected based on theory (here: the correlation between innovativeness and pro-activeness; $\left.\mathrm{r}_{\mathrm{u}}=.544\right)$. For $\mathrm{r}_{\mathrm{m}}$ we select the second smallest correlation between any pairs of variables that is theoretically unrelated. We use the bivariate correlation of both marker variables as an indicator of CMV (here: the correlation between general business planning and customer relations; $r_{m}=.010$, see Table 2$)$. We arrive at $r_{a}=(.544-.010) /(1-.010)^{2}$ $=.54$

The t-statistic to assess the statistical significance of $r_{a}$ is computed as follows:

$$
t_{(\propto / 2, n-3)}=r_{a} / \sqrt{[}\left[\frac{\left(1-r_{a}^{2}\right)}{n-3}\right]=9.77
$$

The test statistic (9.77) suggests that common method variance is not severe.

\subsection{Results}

The age of the respondents varies from 20 to above 50 years. Using cluster analysis, we categorized the respondents into two categories, i.e. those less than versus those above 40 years of age, see Table 3.1.

The respondents' business experience varies from less than five to above 20 years, with the majority having fewer than 15 years of experience. Becker (1993), Gird and Bagraim (2008), Kraiger et al. (1993) and Ployhart and Moliterno (2011) argue that experience with entrepreneurship adds to the ability to successfully execute business operations. More generally, life experience adds to successful entrepreneurship as well (Martin et al., 2013). We therefore distinguish those microfinance debtors with less than 15 years of business experience from those with more than 15 years of business experience.

The education level of the respondents varies from primary through secondary and tertiary education. The majority are those with primary and secondary education, and these respondents represent 89 percent of the total sample. We therefore categorized the respondents in two clusters, i.e. those with primary and secondary education only and those with tertiary degrees. 
The total sample of 235 includes 102 males and 132 females and comprises the Ashaiman branch (79 respondents), the Makola branch (77 respondents) and the Kantamanto branch (79 respondents).

Table 3.1. Descriptives.

\begin{tabular}{lll}
\hline Age of microfinance debtor & $\mathrm{N}$ & Percentage \\
\hline$<40$ years & 110 & 47 \\
$\geq 40$ years & 121 & 52 \\
\hline Years of business experience & & \\
\hline$<15$ years & 176 & 75 \\
$\geq 15$ years & 59 & 25 \\
\hline Level of education & & \\
\hline Primary \& Secondary degree & 208 & 89 \\
Tertiary degree & 27 & 12 \\
\hline Gender & & \\
\hline Male & 102 & 43 \\
Female & 132 & 57 \\
\hline
\end{tabular}

The mean scores for the uniCredit microfinance debtors on the various dimensions of entrepreneurial and business skills vary from 4.20 to 5.82 on a $1-7$ Likert scale, see Table 3.2. See Appendix A for the items underlying the entrepreneurial and business skills variables. The high mean score on customer relations (CR) indicates that entrepreneurs consider customer relations skills as key to their business success. The lower mean of 4.2 for record keeping (RK) suggests that MFI microfinance debtors do not consider this skill indispensable. The standard deviations are fairly low and suggest that the scores on the various dimensions of entrepreneurial and business skills are closely clustered around their means. The mean values therefore adequately represent the sample scores. Correlation analysis (Table 3.2) shows 36 bivariate correlations, all positive. Mean repayment rates correlate negatively with skills related to record keeping (RK) and interpersonal relation (IPR), -0.15 and -0.17 , respectively. Relative to those microfinance debtors lagging behind on their loan repayments, those respondents who repay their loans before due date may be less biased towards socially desirable self-evaluations on entrepreneurship and business skills questions. 
Table 3.2. Descriptives and Correlations of entrepreneurial and business skills variables for uniCredit Ghana.

\begin{tabular}{|c|c|c|c|c|c|c|c|c|c|c|c|c|}
\hline & $\mathrm{N}$ & Mean & SD & GBP & RK & FM & MO & CR & RT & INV & PA & IPR \\
\hline $\begin{array}{l}\text { General business planning (GBP) } \\
\text { (1-7 Likert scale) }\end{array}$ & 235 & 4.8 & 1.14 & & & & & & & & & \\
\hline $\begin{array}{l}\text { Record keeping (RK) } \\
\text { (1-7 Likert scale) }\end{array}$ & 235 & 4.2 & 1.38 & $.58^{*}$ & & & & & & & & \\
\hline $\begin{array}{l}\text { Financial management (FM) } \\
\text { (1-7 Likert scale) }\end{array}$ & 235 & 4.7 & 1.02 & $.52^{\star}$ & $.54^{\star}$ & & & & & & & \\
\hline $\begin{array}{l}\text { Market orientation (MO) } \\
\text { (1-7 Likert scale) }\end{array}$ & 229 & 4.4 & 1.06 & $.49^{*}$ & $.52^{\star}$ & $.49^{\star}$ & & & & & & \\
\hline $\begin{array}{l}\text { Customer Relations (CR) } \\
\text { (1-7 Likert scale) }\end{array}$ & 235 & 5.8 & 0.97 & .01 & .01 & $.28^{\star}$ & .08 & & & & & \\
\hline $\begin{array}{l}\text { Risk taking (RT) } \\
\text { (1-7 Likert scale) }\end{array}$ & 234 & 4.8 & 1.00 & $.22^{*}$ & $.22^{\star}$ & $.28^{\star}$ & $.21^{*}$ & $.30^{*}$ & & & & \\
\hline $\begin{array}{l}\text { Innovativeness (INV) } \\
\text { (1-7 Likert scale) }\end{array}$ & 232 & 4.4 & 1.14 & $.36^{*}$ & $.39^{\star}$ & $.36^{*}$ & $.47^{*}$ & $.18^{\star}$ & $.42^{\star}$ & & & \\
\hline $\begin{array}{l}\text { Pro-activeness (PA) } \\
\text { (1-7 Likert scale) }\end{array}$ & 232 & 4.6 & 1.04 & $.50^{*}$ & $.46^{*}$ & $.46^{\star}$ & $.62^{\star}$ & $.18^{*}$ & $.38^{\star}$ & $.54^{*}$ & & \\
\hline $\begin{array}{l}\text { Interpersonal relationships (IPR) } \\
\text { (1-7 Likert scale) }\end{array}$ & 228 & 4.7 & 1.17 & $.30^{*}$ & $.39^{\star}$ & $.34^{\star}$ & $.40^{*}$ & $.24^{\star}$ & $.30^{*}$ & $.33^{*}$ & $.45^{\star}$ & \\
\hline Repayment rate & 235 & $45 \%$ & 0.49 & -0.02 & $-0.15^{*}$ & -0.09 & -0.10 & -0.05 & -0.02 & -0.11 & -0.11 & $-0.17^{\star}$ \\
\hline
\end{tabular}

* significant at 1 percent level. See Appendix A for the items underlying the variables.

Regarding the relation between age of debtors and the probability to repay their loans, see Table 3.3 , it shows that entrepreneurs above 40 years of age are more likely to repay their loans (48 percent repayment rate) relative to microfinance debtors younger than 40 years (40 percent repayment rate). These repayment rates do not differ statistically significantly ( $p$-value $=$ $0.227)$.

Experience with entrepreneurship proves explanatory for the probability to repay the loan. Mean repayment values vary from 38 percent for the less experienced to 66 percent for the more experienced MFI microfinance debtors. This difference between the less and the more experienced is statistically significant $(p$-value $=0.001)$.

Those debtors with primary or secondary education only are more likely to repay their loans relative to those with tertiary education (47 and 30 percent repayment rate, respectively). These repayment rates are statistically significantly different $(p$-value $=0.095)$.

The relation between gender and loan repayment was established. The highest mean repayment rate (69 percent) was observed for female debtors, which is an indication that females repay loans better than do male debtors. These repayment rates differ statistically significantly (pvalue $=0.001)$. 
Table 3.3. Loan repayment probabilities for age of microfinance debtor, business experience, level of education and gender.

\begin{tabular}{|c|c|c|c|c|}
\hline Age of microfinance debtor & $\mathrm{N}$ & $\begin{array}{l}\text { mean loan } \\
\text { repayment } \\
\text { rate (percent) }\end{array}$ & $\begin{array}{l}\text { standard } \\
\text { deviation } \\
\text { (percent) }\end{array}$ & p-value \\
\hline$<40$ years & 110 & 40 & 49 & 0.227 \\
\hline$\geq 40$ years & 121 & 48 & 50 & \\
\hline \multicolumn{5}{|l|}{ Years of business experience } \\
\hline$<15$ years & 176 & 38 & 49 & $0.000^{*}$ \\
\hline$\geq 15$ years & 59 & 66 & 48 & \\
\hline \multicolumn{5}{|l|}{ Level of education } \\
\hline Primary or Secondary degree & 208 & 47 & 50 & 0.095 \\
\hline Tertiary degree & 27 & 30 & 47 & \\
\hline \multicolumn{5}{|l|}{ Gender } \\
\hline Male & 102 & 14 & 35 & $0.000^{*}$ \\
\hline Female & 132 & 69 & 46 & \\
\hline
\end{tabular}

* significant at 1 percent level

The variables for RT, INV, PA, CR and IPR are aggregated in the entrepreneurial skills sum score; the scores on GBP, RK, FM and MO are summarized by the business skills sum score. Cronbach's alpha values for the entrepreneurial and business skills sum scores are 0.73 and 0.84, respectively. These values are within the acceptance range (Field, 2009; Hutcheson and Sofroniou, 1999). We regress repayment probabilities on these sum scores for entrepreneurial and business skills, see Table 3.4. 
Table 3.4. Binary regression analysis of loan repayment probabilities for uniCredit Ghana, fixed effects.

\begin{tabular}{lrrl}
\hline $\mathrm{N}=225$ & coefficient & S.E. & p-value \\
\hline Entrepreneurial skills & -0.03 & 0.28 & 0.923 \\
Business skills & 0.08 & 0.19 & 0.689 \\
Age of debtor: $\geq 40$ years & -0.22 & 0.59 & 0.708 \\
Business experience: $\geq 15$ years & 1.29 & 0.39 & $0.001^{*}$ \\
Level of education: tertiary degree & -0.07 & 0.59 & 0.902 \\
Gender: female & 2.58 & 0.38 & $0.000^{*}$ \\
Constant & -1.83 & 2.19 & 0.404 \\
\hline
\end{tabular}

* significant at 1 percent level

Neither entrepreneurial nor business skills prove explanatory for loan repayment rates ( $\mathrm{p}$-value $=0.923$ and 0.689 , respectively). Age is not significantly related to loan repayment probabilities $(p$-value $=0.708)$. Loan repayment rates improve with years of experience $(p$-value $=0.001)$. Those microfinance debtors with tertiary education level do not repay their loans better than those with primary or secondary degrees only $(p$-value $=0.902)$. Female MFI microfinance debtors repay their loans better $(p$-value $=0.001)$. The model explains 42 percent of total variance in repayment rates.

\subsection{Conclusions and discussion}

The present study shows that those microfinance debtors who consider themselves endowed with entrepreneurial and business skills, i.e., those who stand out on risk taking, innovativeness, pro activeness, customer relations, interpersonal relations, general business planning, record keeping, financial management and market orientation do not repay loans better than those who consider themselves not endowed with these skills. This suggests that developing entrepreneurial and business skills may not be expected to effectively improve business performance and, therefore, loan repayment rates. This result is consistent with Karlan and Valdivia (2011) and McKenzie and Woodruff's (2013) failure to establish positive effects of skills training on business performance.

Human capital theory postulates that individuals or groups who possess knowledge, skills and other competencies perform better in executing relevant tasks (Becker, 1993; Kraiger et al., 
1993; Ployhart and Moliterno, 2011). Therefore, it was expected that tertiary education translates into better business performance and loan repayment. Our analysis for the Ghanaian case shows, however, that highly educated entrepreneurs do not repay their loans any better relative to those with primary or secondary education only.

Those entrepreneurs endowed with 15 years of business experience systematically outperform those with fewer than 15 years of experience and repay their loans better. This observation is consistent with Lans et al. (2015) who argue that business experience matters for business performance.

Female microfinance debtors repay their loans better than do male entrepreneurs. This result is consistent with, among others, Anthony and Horne (2003), Kabeer (2001), Kevane and Wydick (2001), Ledgerwood (1999), Pronyk et al. (2008), Rahman (1999) and Ridgeway and SmithLovin (1999). More generally, women tend to manifest behaviour that can best be described as social and friendly, more than do men. This may explain better loan repayment rates for female entrepreneurs (Anthony and Horne, 2003).

The present study contributes to the literature by showing that business experience is the only constituent of human capital explanatory for microfinance debtors' loan repayment rates.

Though the present study does not establish any impact of entrepreneurial and business skills on loan repayment rates, acquiring skills is generally recognized as an important constituent of corporate social responsibility strategies adopted by many MFIs (among others, see Seuneke et al., 2013). Further research should rely on longitudinal research designs in order to more accurately examine the impact of skills on loan repayment rates. 


\section{CHAPTER 4}

\section{Perception of microfinance debtors and loan officers on the importance of entrepreneurial and business skills for loan repayment rates}

\section{Based on:}

Agbeko, D., Blok, V., Omta, S.W.F., Van der Velde, G. (2017). Perception of microfinance debtors and loan officers on the relevance of business and entrepreneurial skills for loan repayment in Ghana. In C. Douglas, Y. Dong, H. Wenxuan, S. Binayak (Eds.), Microfinance for Entrepreneurial Development: Sustainability and inclusion in emerging markets (Chapter 5). Basingstoke, United Kingdom: Palgrave Macmillan Publishing. 


\section{CHAPTER 4}

\section{Perception of microfinance debtors and loan officers on the importance of entrepreneurial and business skills for loan repayment rates}

\subsection{Introduction}

Various researchers have indicated that entrepreneurial competencies are positively related to entrepreneurial success (Baron and Ensley, 2006; Baum and Locke, 2004; Chandler and Jansen, 1992; Ucbasaran et al., 2008). This suggests that as individuals acquire skills they perform better in their businesses, consistent with the human capital theory (Becker, 1993). For developing countries, entrepreneurial and business training may have positive effects on the microfinance debtors performance (Cook, 2001; Dumas, 2001; Edgcomb, 2002; Ekpe et al., 2010b; Gray et al., 2011; Karlan and Valdivia, 2011).

With regard to entrepreneurial and business training, it remains unclear what set of entrepreneurial competencies explains microbusiness success. Among others, Mano et al. (2012) argue that business planning skills and market orientation skills effectively improve the performance of entrepreneurs, whereas Edgcomb (2002) emphasizes the importance of financial skills like record keeping and break-even analysis. With regard to microfinance lenders, Karlan and Valdivia (2011) argue that business planning, financial management, customer care and market orientation are the most important entrepreneurial competences. It remains unclear, therefore, what set of entrepreneurial and business competencies should be trained in order to improve business performance and, therefore, loan repayment rates of microfinance debtors.

The objective of this Chapter is to identify what set of entrepreneurial and business competencies are most important for loan repayment rates. Entrepreneurial skills are defined by Chen et al. (1998), Oosterbeek et al. (2010) and Verhees et al. (2012) as the ability to take risk and be innovate and pro-active. Market orientation is defined by Alby et al. (2013) as setting market and profit objectives, and being engaged with market research and analyses. We follow Smith and Perks' (2006) definition of business skills as the ability of entrepreneurs to 
plan their business, keep records, manage their finances and relate to their employees and customers.

We organized focus group discussions with four uniCredit Ghana microfinance loan officers and three microfinance debtors to rank six entrepreneurial and business skills on their relevance for business success and loan repayment rates, i.e., general business management skills, financial management skills, record keeping skills, inter personal skills, customer relations and market orientation skills.

In the next Section we review literature on allegedly important entrepreneurial and business skills. Section 3 presents the methods used. Section 4 discusses the results. Section 5 concludes.

\subsection{Entrepreneurial skills, business skills and loan repayment}

According to the human capital theory, individuals endowed with human capital perform better in executing relevant tasks (Becker, 1993). It is expected that MFI debtors with more knowledge and skills will perform better in their businesses. In the absence of entrepreneurial and business skills, people cannot make use of microfinance effectively (Ekpe et al., 2010b; Idris and Agbim, 2015b; Karlan and Valdivia, 2011; Mutisya and Yarime, 2014). Microfinance should be packaged such that entrepreneurial and business skills development is substantial to MFI assistance (Lensink et al., 2011).

Echtner (1995) states that "entrepreneurship programmes may be one of the most cost effective means of reaching, educating, and significantly empowering local individuals". Gatewood et al. (1995) establish positive effects of entrepreneurship education on business performance. Baron and Ensley (2006) and Seuneke et al. (2013) relate entrepreneurial experience to entrepreneurial success. There is, however, no consensus as to whether skills training is indispensable for microfinance debtors. Yunus (1999) states that entrepreneurial skills are innate and cannot be trained. McKenzie and Woodruff (2013) examine microbusiness training programmes and establish that in many cases the impact of training programmes on business performance is small and does not affect sales nor profitability. Karlan and Valdivia (2011) found in their study on the impact of business training on Peruvian microfinance debtors 'little or no evidence of changes in key outcomes such as business revenue, profits, or employment'. A meta-analysis of entrepreneurial training programmes revealed that most studies did not incorporate both pre- and post- training intervention measures (Martin et al., 2013), which makes the results of most studies unreliable. 
Factors other than entrepreneurial and business skills may also explain business performance and loan repayment rates. Balogun and Alimi (1988) and Ledgerwood (1999) establish that loan default is due to small loan size and poor loan monitoring. Sharma and Zeller (1997) relate loan defaults to lack of willingness among debtors to repay and inaccurate loan application reviews by loan officers. Olomola (2000) finds that high interest rates and delayed loan application procedures increase loan default rates. According to Bloem and Goerter (2001) loan default is caused by poor business decisions by the debtor and unanticipated price changes of merchandise. Kohansal and Mansoori (2009) argue that loan defaults are related to high interest rates imposed by government regulations, monopoly power in the credit market, transaction costs incurred by borrowers and inability of the loan officers to effectively monitor the performance of their debtors. Mensah et al. (2013) observe a negative relation between loan repayment on the one hand, and interest rates, moral hazard and over-borrowing on the other. The lower the interest rates, the fewer microfinance debtors divert their loans into new ventures. Loan diversion is a major cause of loan defaults (Bichanga et al., 2013). Bichanga et al. (2013) also identify inadequate supervision of loan officers and lagging macro-economic growth rates as causes of loan defaults.

\subsection{Methods}

A research was designed to examine the extent to what microfinance debtors and loan officers agree on the importance of entrepreneurial and business skills for business performance and loan repayment rates. The case for this study is uniCredit Ghana. uniCredit Ghana is a nonbank financial institution and has been in operation since 1995. The primary focus of uniCredit is to provide financial services that are specifically tailored to the needs of micro, small and medium sized enterprises.

uniCredit had 655 microfinance debtors as at 12/11/2013. The entire loan list was downloaded and debtors with loan disbursements more than USD 4,000 were excluded from the list resulting in an average loan size of USD 2,000. This is to ensure that the sample consists of microfinance debtors only. Staff loans and salary workers loans were also excluded from the list. Three debtors with good loan repayment track records, i.e., debtors who repaid their loans within seven days after due date, were randomly selected. In addition, four uniCredit loan officers were randomly selected.

The total sample consists of seven debtors and loan officers, both females and six males and ages ranging from 25 to 56 years. Seven participants may be considered an optimal sample size 
because the smaller the number of participants the more participatory the discussions (Kitzinger, 1994, 1995). Different researchers have used group sizes ranging from three to 12 participants, depending on the purpose of the focus groups (Kitzinger, 1994; Kumar et al., 2009; Silverman, 2010).

We examine the extent to what microfinance debtors and MFI loan officers agree on the importance of entrepreneurial and business skills for loan repayment rates.

Figure 4.1. Entrepreneurial and business skills and loan repayment probabilities.

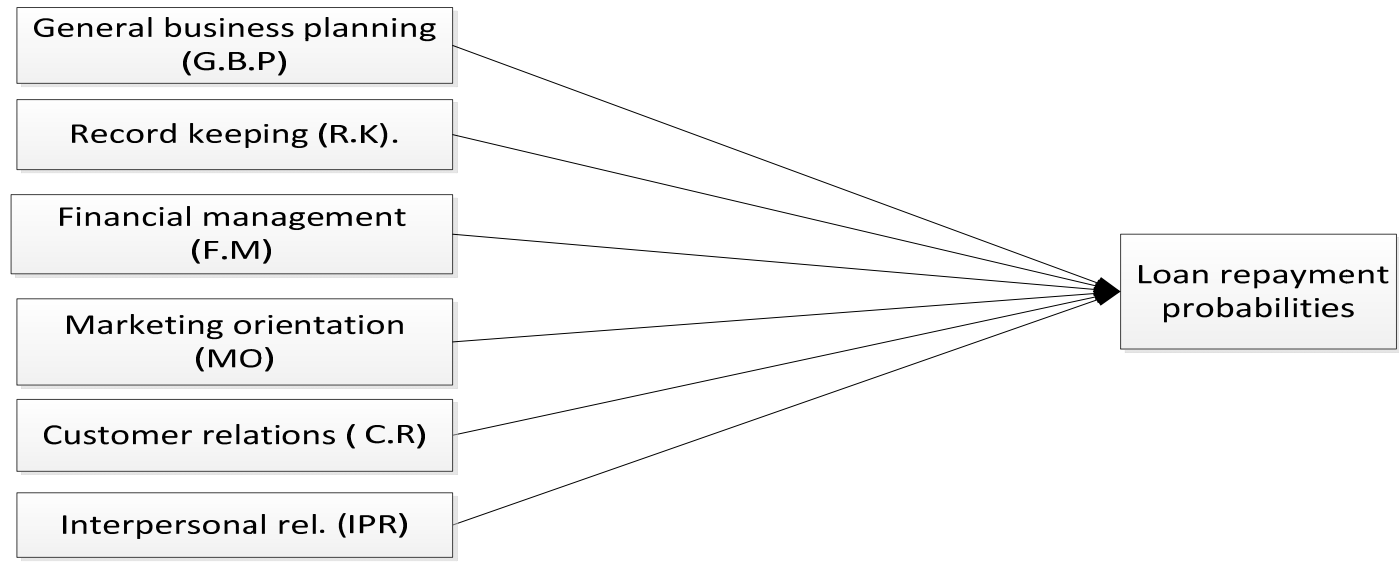

We used focus group discussion because approximately 30 percent of the microbusiness debtors are illiterates. A focus group discussion in the local dialect is most appropriate to involve illiterate debtors. According to Kitzinger (1994), focus groups help participants explore and clarify their views.

Two focus group discussions were organized, for microfinance debtors (three participants) and loan officers (four participants). The focus group discussions took place in the conference room of the Ashaiman branch of uniCredit Ghana limited. All participants were informed about the purpose and content of the study. Guarantees of confidentiality and anonymity were given prior to each focus group discussion. The participants were given a general definition of the following skills:

1. General business planning (GBP): defined as short term planning and budgeting skills.

2. Record keeping (RK): defined as bookkeeping and inventory management skills. 
3. Financial management (FM): defined as cash flow management skills.

4. Market orientation skills (MO): defined as skills for setting objectives related to market shares.

5. Customer relations (CR): defined as understanding customers' needs and perceptions.

6. Interpersonal skills (IPR): defined as management skills.

The focus groups were then held to discuss the alleged importance of these skills. The researcher acted as the facilitator to generate a free flow of information among the respondents. Afterwards, the researcher wrote a comprehensive script of the two focus group discussions. The duration of the focus groups discussions varied from 38 to 58 minutes.

The scripts of both focus group discussions were analysed using content analysis. This was done by importing the scripts into Atlas.ti 7.5 software. The coded output was then used for further analysis to examine the extent to what the focus group participants agree on their rankings of the entrepreneurial and business skills.

\subsection{Results}

The extent to what the focus group participants agree on the importance of entrepreneurial and business skills for loan repayment rates is examined using Cohen's Kappa inter-rater agreement statistic and is calculated for the microfinance debtors and the loan officers. Kappa values of 1 suggest perfect agreement; values below 0 indicate absence of agreement (Viera and Garrett, 2005). For the microfinance debtors focus group $(\mathrm{N}=3)$, we establish a negative value for Kappa (-0.073). This result suggests that there is no agreement (within group comparison) among the microfinance debtors as to what they think is important for loan repayment rates.

The negative value for Kappa (- 0.027) for the loan officers focus group ( $\mathrm{N}=4)$ suggests that loan officers have diverse opinions as to what skills they think are important for microfinance debtors' loan repayment rates.

\section{General business management}

The focus group discussions showed that debtors, both those with good and those with poor loan repayments, claim that planning is crucial. Some debtors plan their activities on daily, weekly or monthly basis. These debtors indicated, however, that long term planning would be 
better. They also stated that the importance of planning depends on the nature of business. Those debtors with good loan repayment typically stock their shops when needed and therefore do not have the problem of expired goods. Those debtors with poor loan repayments typically buy stock in bulk and most often cannot sell all the stock. Most of the inventories expire and thereby cause economic losses. One debtor recounted her experience: 'In July 2013, prior to the Christmas celebrations, I stocked my shop with biscuits and soft drinks, but on the eve of Christmas a new variety of biscuit called Obama biscuits arrived in the country. My biscuits were not being purchased and I ran into big losses. This lesson taught me to be careful in buying goods in bulk.' The loan officers argued that the debtors' poor repayments are due to the debtors' inability to study the market trend and purchase stock accordingly.

\section{Record keeping skills}

The focus group discussants claimed that accurate record keeping is not the practice for those debtors with good loan repayments nor those with poor loan repayments. The debtors claimed that accurate record keeping is too tedious. Some debtors only record end-of-day total inventories. One debtor narrated her ordeal: 'We have employed several shop assistants and all of them stole from the shop, even though they keep very good accounts of our business. I do not see the need for record keeping because now I run the shop with my wife, at any point in time one of us is present, so no need to keep records. However, we try to keep some records because the loan officers use records as a prerequisite for loans.' Record keeping is therefore practice for most debtors, albeit provisionally. The loan officers also emphasized that record keeping is a prerequisite for loan acquisition.

\section{Financial management skills}

The focus group participants do not pay themselves fixed salaries. Rather, they withdraw very little money from their businesses for personal expenses. The few debtors who were able to pay themselves fixed salaries stated that they re-invest most of their salaries back into their businesses. Those debtors with good loan repayments differ from those with poor loan repayments in their skills to accurately design profit statements. Whereas those debtors with good loan repayments accurately account for all indirect expenses, those debtors with poor loan repayments simply subtract purchasing prices from sale prices to arrive at estimated profits. One debtor with poor loan repayments stated: 'Even though I do not pay myself a fixed salary, at the end of every month I compute the cost of all the goods I sold, the difference gives me the 
profit, so I have the confidence that my business is not operating at a loss.' Those focus group participants with good loan repayments claimed to have adequate financial management skills.

\section{Market orientation skills}

The focus group participants argued that setting objectives related to market shares, sales, profits, establishing a position in the product market and conducting market analyses are strategies for large corporations rather than for microbusinesses. The debtors with good loan repayments however expressed their interest in future business expansion, whereas those debtors with poor loan repayments did not. One debtor with good loan repayments commented: 'In fact, setting goals related to market shares and conducting a research so as to position myself strategically in the market is not important at all, what is important is just to handle the customers well!' The loan officers explained that most of the debtors are semi-literates and therefore cannot conduct accurate market analyses.

\section{Customer relations skills}

The focus group discussions revealed that those debtors with good loan repayment records relate warmly to their customers, and regularly have telephone contacts with most of their customers. Those debtors with good loan repayments sometimes sell on credit. Debtors with good loan repayments also discuss the specifications their customers need and supply it accordingly. This strategy allegedly improves sales. One debtor with good loan repayment stated: 'I am very friendly with my customers, and I always call them so I know exactly what they need, sometimes I even buy goods from my suppliers and sell it without bringing the goods to the shop, this way I make high profits.' Excellent customer relations skills are therefore key to loan repayment. The loan officers explained that customer relations skills distinguish those debtors with good loan repayments from those with poor loan repayments.

\section{Interpersonal relation skills}

Those focus group participants with good loan repayments argued that the relationship between the shop owners and their employees is important. The interpersonal relationship between owner and employees translates into the way the employees handle their customers. Those debtors with poor loan repayments argued that most employees cannot be trusted and therefor prefer autocratic relationships with their employees. The loan officers explained that shop owners typically prefer working with close relatives, because most of the shop attendants are 
not faithful in their duties. The loan officers further emphasised that in the Ghanaian community, if shop owners become too close with their staff, their staff will no longer respect them. Autocratic relationships between owner and employees are therefore best.

\subsection{Conclusions and discussion}

Among others, Edgcomb (2002) argues that for developing countries, entrepreneurial and business training may have positive effects on the business performance of microfinance debtors. Karlan and Valdivia (2011) establish that business training does not systematically improve microfinance debtors' performance in terms of business revenue, profits, or employment. The present Chapter examines the extent to what Microfinance Institution (MFI) debtors and loan officers agree on the importance of entrepreneurial and business skills for business performance and loan repayment rates. Two focus group discussions revealed that microfinance debtors do not agree on what skills they think are key. This result suggests that every single microfinance debtor has specific needs for acquiring skills. Training programmes should therefore be tailored towards the needs of the individual entrepreneur.

Disagreement among microfinance debtors on the relevance of entrepreneurial and business skills proves more pronounced for specific skills. Focus group discussions revealed that financial management skills and interpersonal skills are most controversial. Particularly those debtors with good loan repayments acknowledged the relevance of these skills for business success. Those debtors with poor loan repayments did not recognize the need for financial management and interpersonal skills. To some extent there is consensus on the advantages of general business management skills and customer relations skills. To some extent there is also consensus on the irrelevance of record keeping skills. Microfinance debtors do not acknowledge the advantages of accurate record keeping and account for their transactions only provisionally.

Consistent with the lack of consensus among microfinance debtors, MFI loan officers have diverse opinions as to what skills they think are important to enable microfinance debtors repay their loans promptly. For loan officers to adequately evaluate loan applications and support microfinance debtors, they need training to better understand the relevance of entrepreneurial and business skills for microfinance debtors' loan repayment probabilities. 


\section{CHAPTER 5}

\section{The impact of training and monitoring on loan repayment of microfinance debtors in Ghana}

\section{Based on:}

Agbeko, D., Blok, V., Omta, S.W.F., Van der Velde, G. (2017b). The impact of training and monitoring on loan repayment of microfinance debtors in Ghana. Journal of Behavioural and Experimental Finance, pp. 23-29. 


\section{CHAPTER 5}

\section{The impact of training and monitoring on loan repayment of microfinance debtors in Ghana}

\subsection{Introduction}

In developing countries, Microfinance Institutions' (MFI) microfinance debtor repayment rates typically fall short and jeopardize sustainability of both MFIs and microbusinesses. Entrepreneurship training and microfinance debtor monitoring programmes may improve microbusinesses performance and, therefore, loan repayment rates. Empirical evidence remains, however, inconclusive.

As to entrepreneurship training, the human capital theory asserts that those individuals endowed with knowledge, skills and competencies perform better in executing relevant tasks (Becker, 1993; Kraiger et al., 1993; Ployhart and Moliterno, 2011). Entrepreneurship training may improve microbusiness performance and, therefore, loan repayment rates (Edgcomb, 2002; Karlan and Valdivia, 2011; Lensink et al., 2011). Empirical studies however fail to establish that entrepreneurship training programmes systematically improve microbusiness performance (Karlan and Valdivia, 2011; McKenzie and Woodruf, 2013).

Microfinance debtor monitoring may be instrumental for preventing loan diversion, improving the relation between MFI and microbusiness entrepreneur and mitigating information asymmetry between lender and borrower (Behr et al., 2011; Edgcomb, 2002; Kohansal and Mansoori, 2009). Though widely recognized, in the literature there is no empirical evidence on the effectiveness of monitoring for improving loan repayment rates.

The objective of the present Chapter is to empirically establish whether entrepreneurship training and microfinance debtor monitoring programmes improve MFI microfinance debtors' repayment rates. We advance on the literature in two dimensions. First, the present Chapter is the first to empirically examine whether those microfinance debtors who were monitored systematically improve loan repayment performance. Second, we improve on the research design. As opposed to previous literature, we compare a baseline study with one and half year follow-up repayment rates, after having introduced training and monitoring interventions. This longitudinal research design better allows for examining the advantages of training and 
monitoring programmes. As opposed to previous studies, we rely on MFI microfinance debtor files and collect objective loan repayment data. Results show that training programmes do not improve loan repayment rates; microfinance debtor monitoring programmes prove advantageous.

In Section 2 we discuss literature on entrepreneurship training and monitoring. Section 3 presents the data and methods. Section 4 provides the results. Section 5 concludes.

\subsection{Entrepreneurship training and monitoring programmes}

Consistent with human capital theory, various studies argue that entrepreneurial and business competencies improve entrepreneurial performance (Baron and Ensley, 2006; Baum and Locke, 2004; Chandler and Jansen, 1992; Newman et al., 2014; Ucbasaran et al., 2008). Entrepreneurship training may help microbusiness entrepreneurs use microfinance more effectively (Ekpe et al., 2010; Idris and Agbim, 2015; Karnani, 2007) and, therefore, alleviate their poverty (Karlan and Valdivia, 2011; Mutisya and Yarime, 2014).

Lensink et al. (2011) use data from 61 countries and empirically establish that those microfinance debtors who participate in training programmes improve on their business performances and repay their loans better. Echtner (1995) considers entrepreneurship programmes the most cost effective means of educating and empowering individual entrepreneurs.

Others argue that training programmes fail to effectively improve microfinance debtors' repayment rates. Karlan and Valdivia (2011) do not find any effect of training programmes participation and conclude that training may improve performance of only few programme participants. McKenzie and Woodruff (2013) empirically establish that training programmes typically have only small positive effects on business practices and do not significantly improve sales nor profitability. More generally, Yunus (1999) argues that entrepreneurial skills are innate and therefore cannot be trained.

Microfinance debtor monitoring programmes involve MFI loan officers to continuously monitor their debtors' business performance, provide tailored and informal on site business advice and help entrepreneurs access business related networks. Balogun and Alimi (1988) and Ledgerwood (1999) consider poor monitoring practices a major cause of loan defaults. At the individual level, effective monitoring requires loan officers to acquire specific entrepreneurial and coaching competencies. At the institutional level, MFIs need organizational structures 
specifically designed to facilitate this process of monitoring. Lensink et al. (2011) conclude that those MFIs that continuously monitor their debtors have better performance than those MFIs that provide financial services only. Bichanga and Aseyo (2013), Elaine and Barton (1998) and Godquin (2004) conclude that non-financial services such as primary health, basic literacy, market information and informal occupational and business skills training positively influence business performance. Kohansal and Mansoori (2009) and Mensah et al. (2013) argue that monitoring helps prevent loan diversion. Edgcomb (2002) and Elaine and Barton (1998) state that provision of non-financial services such as business monitoring deepens the relation of the debtors with the MFI. Monitoring is instrumental for motivating debtors to repay loans promptly (Mirpourian et al., 2015). Behr et al. (2011) argue that monitoring helps mitigate information asymmetry between lender and borrower and, therefore, improves loan repayment rates. Following Kuzilwa (2005), training and monitoring should be considered a joint effort.

\subsection{Methods}

Studies on the advantages of entrepreneurship training typically rely on cross section data and therefore cannot adequately assess the advantages of training programmes. This leaves the results of most studies unreliable (Martin et al., 2013; McNally and Kay, 2013). The present Chapter advances on these studies and examines the impact of training and monitoring interventions by conducting a two-step longitudinal approach. We collected baseline data on 229 microfinance debtors. One and half year later, after having introduced training and monitoring interventions, we collected follow-up data on these 229 debtors. This study design better allows for examining our research question: What is the impact of training and monitoring programmes on loan repayment rates of microfinance debtors?

The study site for this research is a Ghanaian MFI, where the first author of this Chapter has been employed as manager. This allowed for access to loan repayment data. The primary focus of the MFI is to provide financial services that are specifically tailored towards the needs of micro, small and medium scale enterprises.

The mission of the MFI case is to develop easily accessible financial products. As of 2011, the MFI had twelve branches, with an institutional deposit of USD 39 million deposited by 71 thousand customers and loans portfolio of USD 24 million with 3,5 thousand microfinance debtors (Mix-Market, 2015). The loans portfolio is categorized into three categories. The first 
is the corporate loans category with business loans larger than USD 50 thousand. It accrues to 30 percent of the total loans portfolio, and shows repayment rates above 85 percent. The second category is the business loans sector with loans ranging from USD 4 thousand to USD 50 thousand. This category equals 38 percent of the loans portfolio and shows a 77 percent repayment rate. The third category comprises of microloans below USD 4,000. This category constitutes 32 percent the MFI loans portfolio of loans and shows a 45 percent repayment rate. Loan repayment is defined as full repayment of principal and interest before due date, on due date, or seven days past due date.

For our case analysis, the entire loan list was downloaded and microfinance debtors with loan disbursements above USD 4,000 were excluded as these microfinance debtors cannot be considered microfinance debtors. Staff loans and salary workers loans were also excluded. From the microfinance debtors loan portfolio, 235 were randomly selected from the total data on 3,277 debtors and included in the baseline database. Baseline data were collected in April, 2013. After having introduced the interventions, we collected follow-up repayment data in October, 2014. For 229 respondents we had data on loan repayments at both baseline and follow-up date, leaving the sample size at 229 observations. Loan officers then randomly invited $25 \%$ percent or 60 microfinance debtors to participate in either of the four interventions; no intervention, monitoring, training, or both monitoring and training.

Figure 5.1. Total sample strata, by intervention.

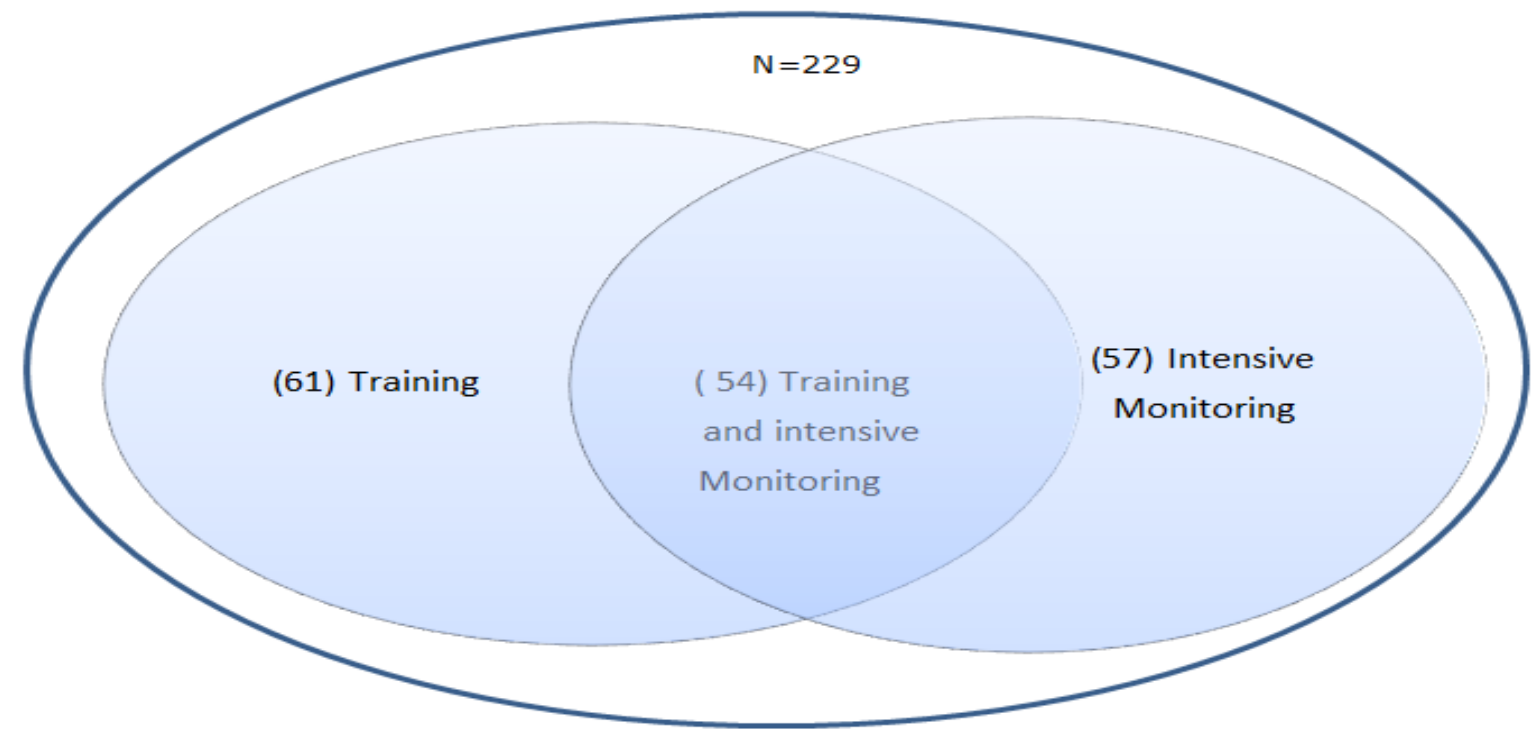




\section{The training intervention}

Following Bichanga and Aseyo (2013), Echtner (1995), Elaine and Barton (1998), Kohansal and Mansoori (2009), Lensink et al. (2011) and Mensah et al. (2013), entrepreneurial and business skills may improve business performance and, therefore, loan repayment rates. In total 115 microfinance debtors were trained, see Figure 5.1. These 115 microfinance debtors participated in a five days training programme aimed at developing entrepreneurial and business skills. The training was organized in five batches to maximize debtor participation and understanding. The impact of the training may depend on the skills, experience and qualifications of the trainer. For this training intervention we therefore hired a professional trainer associated with Freedom from Hunger, a United Nation based non-profit organisation. Freedom from Hunger is widely recognized as leader in credit-with-education programmes and is responsible for training interventions in eighteen countries and over 50 financial institutions and 700,000 trainees (Karlan and Valdivia, 2011). To ensure maximum participation the training was provided in the Ghanaian local language Twi. Microfinance debtors were trained in three main modules, the first two of which lasted for two days each, the last module lasted for a day, see appendix B.

The first training module focused on building business operations skills. These include general business planning, record keeping and financial management skills. General business planning skills involve short term planning and budgeting skills (Smith and Perks, 2006; Van Dyk et al., 1992). Record keeping skills include book keeping and inventory management skills (Edgcomb, 2002; Karlan and Valdivia, 2011; Mano et al., 2012; Van Dyk et al., 1992). Financial management skills relate to the ability to design the income statement (Edgcomb, 2002; Karlan and Valdivia, 2011; Mano et al., 2012; Smith and Perks, 2006).

The second training module aimed at acquiring entrepreneurial skills. These include the willingness to take risks and be innovative and pro-active (Verhees et al., 2012; Wiklund et al., 2009). As to the willingness to take risk, the trainer followed Chen et al. (1998), Oosterbeek et al. (2010) and Verhees et al. (2012) and discussed issues of accountability, decision making under pressure and the use of check list procedures. Consistent with Chen et al. (1998) and Verhees et al. (2012), training on innovativeness involved discussions on how to introduce new products and services and how to explore new markets and methods of production. The debtors' pro-activeness is trained by means of discussions on the willingness to start a new activity, to be the first to respond to new opportunities, and the debtors' proficiency with starting new 
activities (Verhees et al., 2012). The second training module followed Smith and Perks (2006) and Van Dyk et al. (1992) and emphasized the need to maintain customer relations and interpersonal relations.

The third training module discussed market orientation skills and focused on how to set sales, profit and market share objectives. The relevance of market orientation skills for microbusiness performance is argued for by, among others, Alby et al. (2013), Chen et al. (1998), Edgcomb (2002), Oosterbeek et al. (2010), Otero-Neira et al. (2013) and Verhees et al. (2012).

\section{The monitoring intervention}

The MFI typically monitors its microfinance debtors at an average of four times per year. For our monitoring intervention we intensified the monitoring frequency from four to 24 times per year. In total 111 microfinance debtors were monitored, see Figure 5.1. These microfinance debtors were assigned to the loan officers, 11 per the first loan officer and 10 per all the other officers. The loan officers were tasked to visit every single debtor on site, twice per month for 18 months starting from April 2013 to October 2014. To minimize cost per visit, the locations of the debtors were zoned based on proximity of the sales locations of other debtors, such that debtors who were close to each other were visited on the same day. The monitoring involved discussing business challenges faced by the debtor. The officers informally advised the individual debtors on how to improve their businesses methods, introduced the debtors to specific business networks, supported debtors to get involved in relevant supply chains and shared local financial and economic news.

Following Bichanga and Aseyo (2013), Echtner (1995), Elaine and Barton (1998), Kohansal and Mansoori (2009), Lensink et al. (2011) and Mensah et al. (2013), we examine the extent to which training and monitoring programmes improve loan repayment rates of MFIs microfinance debtors. Following Kuzilwa (2005), training and monitoring interventions should be considered a joint effort. More specifically, we hypothesize that:

H1. Improvements in repayment rates across time are more pronounced for those microfinance debtors who are monitored intensively, relative to those debtors who are neither trained nor monitored. 
H2. Improvements in repayment rates across time are more pronounced for those microfinance debtors who participate in entrepreneurship training programmes, relative to those debtors who are neither trained nor monitored.

H3. Improvements in repayment rates across time are more pronounced for those microfinance debtors who are both trained and monitored intensively, relative to those debtors who are trained only or monitored only.

Figure 5.2. Intensive monitoring, training and loan repayment rate.

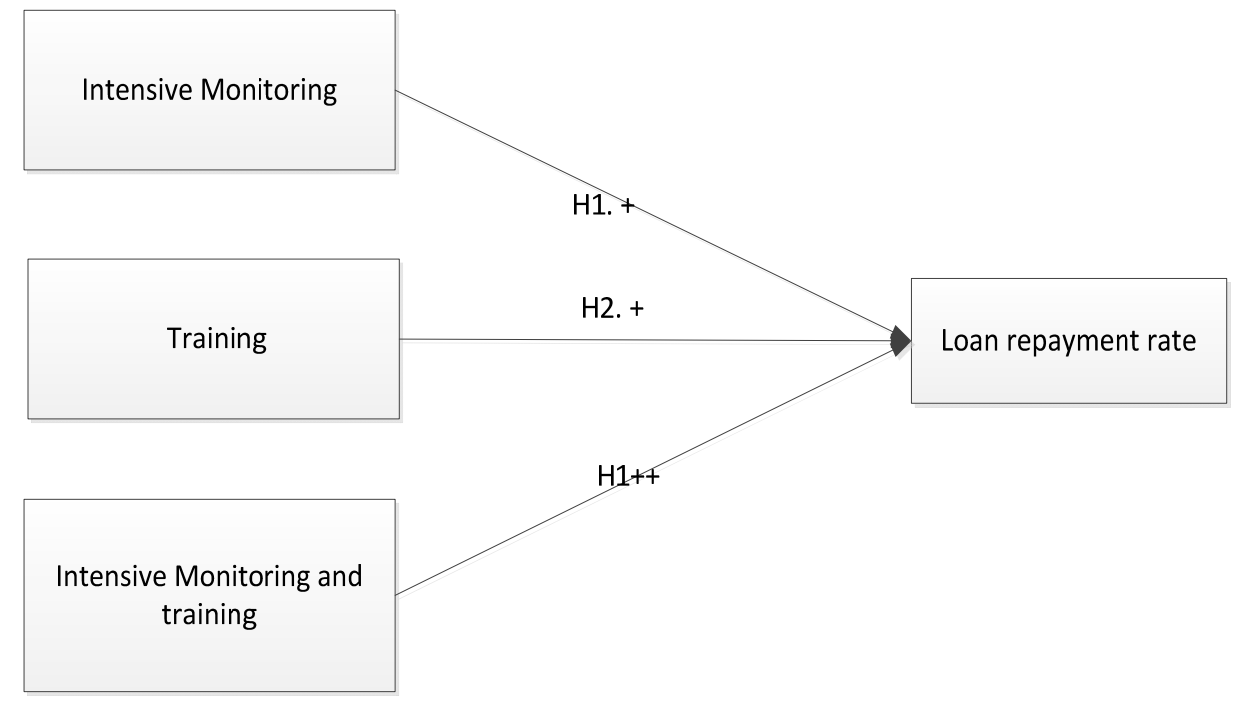

According to Lans et al. (2015), business experience matters for business performance. The human capital theory postulates that education and work experience add to successful entrepreneurship (Martin et al., 2013). Based on this theory, Becker (1993), Kraiger et al. (1993) and Ployhart and Moliterno (2011) assert that individuals or groups with experience and knowledge perform better in executing relevant tasks. Based on cluster analysis of the 229 microfinance debtors sample, not shown here, we established that those microfinance debtors with tertiary degrees or more than 15 years business experience show significantly higher repayment rates. In our assessment of the efficacy of training and monitoring interventions we therefore distinguish those with more than 15 years of business experience and those with tertiary education from the less experienced and those with primary or secondary degrees only. 
Women tend to manifest behaviours that can best be described as social, friendly and risk averse, more than do men (Anthony and Horne, 2003). Female microfinance debtors repay their loans better than do male entrepreneurs (Anthony and Horne, 2003; Kabeer, 2001; Kevane and Wydick, 2001; Ledgerwood, 1999; Pronyk et al., 2008; Rahman, 1999; Ridgeway and SmithLovin, 1999). In our assessment of the efficacy of monitoring and training interventions we therefore distinguish between male and female entrepreneurs.

\subsection{Results}

The 229 total sample overall repayment rate is 45 percent, see Table 5.1. During the one and half year time span between baseline and follow-up date, overall repayment rates have increased 20 percentage points from baseline performance. The 57 control group microfinance debtors show a 42 per cent repayment rate at baseline date. These entrepreneurs are monitored four times per year on average. This monitoring frequency is typical for MFIs. For these 57 control group microfinance debtors this monitoring frequency is left unchanged. In the absence of any interventions, control group repayment rates decreased considerably over time, underlining the need for interventions. The substantial decrease in repayment rates may be explained by significant increases in inflation rates and the macro economic downturn during the time span. As opposed to those 57 control group debtors that were neither monitored intensively nor trained, those 57 microfinance debtors that were monitored intensively show improved repayment rates. Relative to monitoring, training programmes prove less advantageous. 
Table 5.1. Descriptives: loan repayment rates at baseline and follow-up date.

\begin{tabular}{lccc}
\hline & $\begin{array}{c}\text { Number of } \\
\text { microfinance } \\
\text { debtors }\end{array}$ & $\begin{array}{c}\text { Baseline } \\
\text { repayment } \\
\text { rate }\end{array}$ & $\begin{array}{c}\text { Follow-up } \\
\text { repayment } \\
\text { rate }\end{array}$ \\
\hline Total sample & 229 & 0.45 & 0.65 \\
\hline No intervention (control group) & 57 & 0.42 & 0.23 \\
\hline Intensive monitoring & 57 & 0.42 & 0.93 \\
\hline Training & 61 & 0.56 & 0.46 \\
\hline Intensive monitoring and training & 54 & 0.41 & 0.96 \\
\hline Education & 203 (prim \& sec) & .46 & .65 \\
\hline Business experience & $26($ tertiary $)$ & .42 & .59 \\
\hline Gender & $166(<15$ years $)$ & .46 & .64 \\
\cline { 2 - 4 } & $63(>15$ years $)$ & .43 & .67 \\
\hline
\end{tabular}

More generally, the pronounced differences between baseline and follow-up statistics underline the need for distinguishing within-effects (time effects) from between-effects (effects of interventions for different sample strata) when assessing the advantages of training and monitoring programmes. The pronounced differences across both time and sample strata also suggest interactions between time and intervention: Systematic changes in repayment rates over time may differ for particular interventions.

Using repeated measures ANOVA procedures, repayment rates for those microfinance debtors who were trained or monitored intensively are compared to repayment rates for those microfinance debtors who did not receive any intervention during the baseline and follow-up time frame (see Table 5.2). Results hold for repeated measures logit procedures, available upon request from the authors. 
Table 5.2. Loan repayment rates: training and monitoring interventions versus no intervention, repeated measures ANOVA.

\begin{tabular}{|c|c|c|c|c|c|c|c|c|c|c|c|c|}
\hline \multirow[t]{3}{*}{ Interventions } & \multirow[t]{3}{*}{$\mathbf{N}$} & \multirow{3}{*}{$\begin{array}{l}\text { Repayment } \\
\text { rate } t_{1} \\
\text { (baseline) }\end{array}$} & \multirow{3}{*}{$\begin{array}{l}\text { Repayment } \\
\text { rate } t_{2} \\
\text { (follow-up) }\end{array}$} & \multicolumn{5}{|c|}{ Between-subjects effect } & \multirow{2}{*}{\multicolumn{2}{|c|}{ Time effect }} & \multirow{2}{*}{\multicolumn{2}{|c|}{$\begin{array}{c}\text { Interaction } \\
\text { effect } \\
\text { (between- } \\
\text { subjects*time) }\end{array}$}} \\
\hline & & & & $\begin{array}{c}\text { Intensive } \\
\text { Monitoring }\end{array}$ & \multicolumn{2}{|c|}{ Training } & \multicolumn{2}{|c|}{$\begin{array}{c}\text { Intensive } \\
\text { Monitoring } \\
\text { and training }\end{array}$} & & & & \\
\hline & & & & F-stat p-value & F-stat & p-value & F-stat & p-value & F-stat & p-value & F-stat & p-value \\
\hline $\begin{array}{l}\text { No intervention } \\
\text { (control group) }\end{array}$ & 57 & 0.42 & 0.23 & & & & & & n.a. & n.a. & n.a. & n.a. \\
\hline $\begin{array}{l}\text { Model 1: } \\
\text { Intensive } \\
\text { monitoring } \\
\text { (control group: no } \\
\text { intervention) }\end{array}$ & 57 & 0.42 & 0.93 & $41.410 .01 * *$ & & & & & 7.05 & $0.01 * *$ & 34.84 & $0.01 * *$ \\
\hline $\begin{array}{l}\text { Model 2: } \\
\text { Training } \\
\text { (control group: no } \\
\text { intervention) }\end{array}$ & 61 & 0.56 & 0.46 & & 9.23 & $0.01 * *$ & & & 4.98 & $0.03 *$ & 0.53 & 0.47 \\
\hline $\begin{array}{l}\text { Model 3: } \\
\text { Intensive } \\
\text { monitoring and } \\
\text { training } \\
\text { (control group: } \\
\text { Intensive } \\
\text { Monitoring) }\end{array}$ & 54 & 0.41 & 0.96 & & & & 0.04 & 0.84 & 96.23 & $0.01 * *$ & 0.19 & 0.67 \\
\hline
\end{tabular}


For those microfinance debtors neither trained nor monitored, loan repayment decreased from 42 to 23 percent within one and half years after baseline date, indicating deterioration of loan repayment by 19 percentage points, see Table 5.2. This decrease is statistically significant (paired-samples t-statistic, $\mathrm{p}$-value $=0.01$, not shown here).

For those microfinance debtors who were monitored intensively, average repayment rate across the 18 months' time frame is 68 percent and significantly different from 33 percent control group repayment rate $(\mathrm{F}$-statistic $=41.41, \mathrm{p}$-value $=0.01)$, see Table 5.2, Model 1 .

Monitored debtors' repayment rates improved from 42 to 93 percent at follow-up date. This 51 percentage points improvement is statistically significant $(\mathrm{F}$-statistic $=7.05$, p-value $=0.01)$. This 51 percentage points improvement is different from control group dynamics (F-statistic $=$ $34.84, \mathrm{p}$-value $=0.01)$. Improvement over time is more pronounced for those debtors who are monitored: Intensive monitoring improves repayment rates.

Those microfinance debtors who were trained showed a 51 percent average repayment rate between baseline and follow-up date, see Model 2. Although this cross period repayment rate is better than 33 percent control group average repayment rates $(\mathrm{F}$-statistic $=9.23$, p-value $=$ 0.01), trained debtors decrease repayments from 56 at baseline date to only 46 for every 100 loans at follow-up date $(\mathrm{F}$-statistic $=4.98, \mathrm{p}$-value $=0.03)$. This decrease in repayment rate over time is not different from control group dynamics $(F$-statistic $=0.52$, p-value $=0.47)$. Training programmes fail to mitigate the control group trend of decreasing repayment rates over time.

Repayment rates for those microfinance debtors who were both trained and monitored are compared to repayment rates for those microfinance debtors who were intensively monitored, see Model 3. This allows for examining interaction effects between training and monitoring interventions. Results show that the combination of training and intensive monitoring is only marginally better than intensive monitoring only, suggesting that training programmes do not add to intensive monitoring programmes.

Education, business experience and gender may influence the efficacy of monitoring interventions, see Table 5.3. 
Table 5.3. Loan repayment rates: education, business experience and gender, repeated measures ANOVA.

\begin{tabular}{|c|c|c|c|c|c|c|c|c|c|c|}
\hline \multirow[t]{2}{*}{ Monitoring intervention } & \multirow[t]{2}{*}{$\mathbf{N}$} & \multirow[t]{2}{*}{$\begin{array}{c}\text { Repayment } \\
\text { rate t1 } \\
\text { (baseline) }\end{array}$} & \multirow[t]{2}{*}{$\begin{array}{l}\text { Repayment } \\
\text { rate } t 2 \\
\text { (follow-up) }\end{array}$} & \multirow{2}{*}{$\begin{array}{l}\text { Average } \\
\text { repayment } \\
\text { rate } \\
\text { (cross period) }\end{array}$} & \multicolumn{2}{|c|}{$\begin{array}{c}\text { Between- } \\
\text { subjects effect }\end{array}$} & \multicolumn{2}{|c|}{ Time effect } & \multicolumn{2}{|c|}{$\begin{array}{c}\text { Interaction effect } \\
\text { (between- } \\
\text { subjects*time) }\end{array}$} \\
\hline & & & & & F-stat & p-value & F-stat & $\mathrm{p}$-value & F-stat & p-value \\
\hline \multirow{2}{*}{$\begin{array}{l}\text { Model 4: } \\
\text { Intensive monitoring and tertiary } \\
\text { education } \\
\text { (control group: monitored only, } \\
\text { primary or secondary degree) }\end{array}$} & \multirow[t]{2}{*}{57} & $\begin{array}{c}0.41 \text { prim.\& sec } \\
(\mathrm{n}=49)\end{array}$ & $\begin{array}{c}0.94 \text { prim \& sec } \\
(\mathrm{n}=49)\end{array}$ & 0.67 prim \& sec & \multirow[t]{2}{*}{0.02} & \multirow[t]{2}{*}{0.89} & \multirow[t]{2}{*}{15.45} & \multirow[t]{2}{*}{$0.01 * *$} & \multirow[t]{2}{*}{0.46} & \multirow[t]{2}{*}{0.50} \\
\hline & & $\begin{array}{c}0.50 \text { tertiary } \\
(n=8)\end{array}$ & $\begin{array}{l}0.88 \text { tertiary } \\
(n=8)\end{array}$ & 0.69 tertiary & & & & & & \\
\hline \multirow{2}{*}{$\begin{array}{l}\text { Model 5: } \\
\text { Intensive monitoring and business } \\
\text { experience } \\
\text { (control group: monitored only, } \\
\text { unexperienced) }\end{array}$} & \multirow[t]{2}{*}{57} & $\begin{array}{c}0.38 \text { unexp } \\
(n=45)\end{array}$ & $\begin{array}{c}0.91 \text { unexp } \\
(n=45)\end{array}$ & 0.65 unexp & \multirow[t]{2}{*}{3.19} & \multirow[t]{2}{*}{0.08} & \multirow[t]{2}{*}{23.38} & \multirow[t]{2}{*}{$0.01 * *$} & \multirow[t]{2}{*}{0.35} & \multirow[t]{2}{*}{0.56} \\
\hline & & $\begin{array}{c}0.58 \exp \\
(n=12)\end{array}$ & $\begin{array}{c}1.00 \exp \\
(\mathrm{n}=12)\end{array}$ & $0.79 \exp$ & & & & & & \\
\hline \multirow{2}{*}{$\begin{array}{l}\text { Model 6: } \\
\text { Intensive monitoring and gender } \\
\text { (control group: monitored only, } \\
\text { male entrepreneur) }\end{array}$} & \multirow[t]{2}{*}{57} & $\begin{array}{c}0.36 \text { male } \\
(n=28)\end{array}$ & $\begin{array}{c}0.93 \text { male } \\
(n=28)\end{array}$ & 0.65 male & \multirow[t]{2}{*}{0.87} & \multirow[t]{2}{*}{0.36} & \multirow[t]{2}{*}{40.67} & \multirow[t]{2}{*}{$0.01 * *$} & \multirow[t]{2}{*}{0.59} & \multirow[t]{2}{*}{0.44} \\
\hline & & $\begin{array}{c}0.48 \text { female } \\
(\mathrm{n}=29)\end{array}$ & $\begin{array}{c}0.93 \text { female } \\
(\mathrm{n}=29)\end{array}$ & 0.71 female & & & & & & \\
\hline
\end{tabular}

*significant at 5 percent level; ** significant at 1 percent level 
Those debtors with tertiary degrees do not repay their loans any better than those with primary and secondary education only $(\mathrm{F}$-statistic $=0.02$, p-value $=0.89)$, see Table 5.3, Model 4. Both these 49 poorly and 8 highly educated entrepreneurs improved upon their repayment performance over time $(\mathrm{F}$-statistic $=15.45, \mathrm{p}$-value $=0.01)$. This result suggests that intensive monitoring is as effective for those with primary and secondary education as well as for those with tertiary degrees $(\mathrm{F}$-statistic $=0.46, \mathrm{p}$-value $=0.50)$.

Those debtors with more than 15 years of business experience repay their loans better than do less experienced entrepreneurs $(F$-statistic $=3.19, p$-value $=0.08)$, see Model 5 . Both these 45 unexperienced and 12 experienced entrepreneurs improved upon their repayment performance over time $(\mathrm{F}$-statistic $=23.38, \mathrm{p}$-value $=0.01)$. Intensive monitoring is equally effective for those with and without business experience $(\mathrm{F}$-statistic $=0.35, \mathrm{p}$-value $=0.56)$.

Between baseline and follow-up date, average repayment rates for females equal those for males $(\mathrm{F}$-statistic $=0.87, \mathrm{p}$-value $=0.36)$, see Model 6. Both female and male entrepreneurs improved upon their repayment rates during baseline and follow-up date (F-statistic $=40.67$, p-value $=$ 0.01). Intensive monitoring proves as effective for female as well as for male entrepreneurs (Fstatistic $=0.59, \mathrm{p}$-value $=0.44)$.

\subsection{Conclusions and discussion}

Using objective data on loan repayments of MFI microfinance debtors, the present Chapter empirically examines the extent to which entrepreneurship training and intensive monitoring programmes improve loan repayment rates for microfinance debtors in developing countries. We compare baseline loan repayment data with one and half year follow-up data for 229 microfinance debtors, after having introduced monitoring interventions for 57 debtors, training interventions for 61 debtors and both training and monitoring interventions for 54 debtors.

Entrepreneurship training programmes also fail to improve loan repayment rates. This result is consistent with Karlan and Valdivia (2011) and McKenzie and Woodruf's (2013) failure to empirically establish any causality between training and loan repayment performance. Contrary to the findings of Kuzilwa (2005), training programmes do not add to the effectiveness of monitoring interventions. The absence of any impact from training on repayment performance is consistent with Yunus' (1999) argument that entrepreneurial skills are innate and therefore cannot be trained. 
MFIs typically monitor its debtors four times per year. Results show that those debtors monitored four times per year systematically decrease their repayment rates over time. This result suggests that moderately intensive monitoring programmes fail to improve loan repayment rates. Intensive monitoring programmes successfully improve loan repayment rates. Relative to those microfinance debtors monitored only four times per year, those monitored intensively significantly improve repayment performance. Intensive monitoring is equally effective for highly and poorly educated, experienced and unexperienced, female and male microfinance debtors: MFIs may significantly improve repayment rates should they consistently monitor their microfinance debtors intensively. Intensive monitoring programmes are labour intensive and therefore costly. Further research should focus on cost-benefit analyses of intensive monitoring programmes from the perspective of the MFI. 


\section{CHAPTER 6}

Discussion and conclusions 


\section{CHAPTER 6 \\ Discussion and conclusions}

\subsection{Introduction}

This Chapter discusses the main findings on the four research questions as outlined in Chapter 1 and assesses the main research question: 'To what extent do corporate social responsibility strategies, entrepreneurial and business skills and programmes for training and monitoring improve loan repayment rates of microfinance debtors in developing countries?'

This Chapter is organized as follows. Section 2 discusses the conclusions regarding the four research questions. Section 3 elaborates on the theoretical and methodological contributions. Section 4 derives policy implications. Section 5 concludes with limitations of this research.

\subsection{Conclusions regarding the research questions}

As to the first research question - To what extent do corporate social responsibility strategies improve loan repayment rates of microfinance debtors? - we conclude that MFIs should consider Corporate social responsibility (CSR) strategies a business opportunity rather than an expense. CSR strategies may be defined as providing for both financial and social empowerment services. Social empowerment services may include primary health care services, occupational skills training for microfinance debtors, debtor meetings and debtor monitoring programmes. Based on the case study of uniCredit Ghana MFI, we conclude that CSR strategies contribute to public support for the MFI. This helps raise deposits and improves funding opportunities and loan repayment rates. Those MFIs that adopt CSR strategies are expected to improve their sustainability, more than do MFIs that specialize in providing financial services only. As our results suggest that skills are important for microbusiness performance, the next Chapter examines what entrepreneurial and business skills really matter for microbusiness success.

As regards the second research question - What entrepreneurial and business skills are important for loan repayment of microfinance debtors? - we conclude that those microfinance debtors who consider themselves endowed with entrepreneurial and business skills do not repay loans better than those microfinance debtors lacking these skills. This result suggests that 
developing entrepreneurial and business skills may not be expected to effectively improve business performance and, therefore, loan repayment rates. Our findings are consistent with those of Karlan and Valdivia (2011) and McKenzie and Woodruff (2013).

We establish that highly educated entrepreneurs do not repay their loans any better relative to those with primary or secondary education only. Consistent with Lans et al. (2015) we observe that business experience matters for business performance. Entrepreneurs with business experience systematically outperform the less experienced and repay their loans better. Consistent with Anthony and Horne (2003), Kabeer (2001), Kevane and Wydick (2001), Ledgerwood (1999), Pronyk et al. (2008), Rahman (1999) and Ridgeway and Smith-Lovin (1999), we observe that female microfinance debtors repay their loans better than do male entrepreneurs. Anthony and Horne (2003) explain better loan repayment rates for women and argue that women tend to manifest social and friendly behaviour, more than do men. As our analysis of our total sample of microfinance debtors does not show any impact of entrepreneurial and business skills on loan repayment rates, the next Chapter examines whether this finding may be explained by lack of consensus among microfinance debtors as to what skills really are important for microbusiness performance.

As regards the third research question - To what extent do microfinance debtors and MFI loan officers agree on the importance of specific entrepreneurial and business skills for loan repayment rates? - we observe that microfinance debtors do not agree on what skills they think are important for loan repayment probabilities. Apparently, every single microfinance debtor needs to acquire specific skills. Consequently, training programmes should be tailored towards the needs of the individual microfinance debtor. MFI loan officers neither agree on the ranking of specific skills they think are important to enable microfinance debtors repay their loans promptly. This result suggests that MFI loan officers should be trained to better understand the relevance of specific entrepreneurial and business skills for microfinance debtors' loan repayment probabilities.

Our examination of the fourth research question - What is the impact of training and monitoring programmes on loan repayment rates of microfinance debtors? - shows that training interventions do not improve loan repayment rates. Our results are consistent with those of Karlan and Valdivia (2011) and McKenzie and Woodruf's (2013). Contrary to the findings of Kuzilwa (2005), training interventions neither add to the effectiveness of monitoring interventions. The absence of any impact of training on repayment performance is consistent 
with Yunus' (1999) argument that entrepreneurial skills are innate and therefore cannot be trained. Whereas most MFIs monitor their microfinance debtors moderately intensively, we observe that moderately intensive monitoring programmes fail to improve loan repayment rates. We establish that intensive monitoring programmes significantly improve loan repayment rates. Intensive monitoring is equally effective for highly and poorly educated, experienced and unexperienced, female and male microfinance debtors: MFIs may significantly improve repayment rates should they consistently monitor their microfinance debtors intensively.

\subsection{Theoretical and methodological contributions}

Human Capital theory was proposed by Schultz (1961) and further developed by Becker (1976). Schultz argues that both knowledge and skills are a form of capital, and that this capital is a product of deliberate investment. The concept of human capital implies an investment in people through education and training. Bruderl et al. (1992) were the first to apply human capital theory in the entrepreneurial context by arguing that although the general application of human capital theory is on employees, it should apply to entrepreneurs as well. Accordingly, those entrepreneurs endowed with higher general and specific human capital may be expected to show better performance than those with lower levels. However, Leitao and Franco (2008) emphasize that empirical research has obtained a range of results regarding this relationship between human capital and performance, but those results are not conclusive.

Within the concept of human capital, we distinguish between education, training and business experience. Education refers to the level of schooling that employees or entrepreneurs possess. The level of education may benefit the firm, because education enhances the ability to understand, create and process information quicker compared to individuals without education (Nelson and Phelps, 1966). Hence, we expected a positive effect of education, as the level of education of the debtor may be conducive in absorbing knowledge and transforming this knowledge into performance. Our results show that highly educated microfinance debtors do not repay their loans any better relative to those with primary or secondary education only. This research finding is inconsistent with the human capital theory.

As training is targeted at acquiring specific skills, training of employees and entrepreneurs may be assumed to increase the human capital of the firm by improving knowledge and capabilities (Cohen and Levinthal, 1990). Yet, empirical evidence is not conclusive about the role of 
training for business performance. For instance, Caloghirou et al. (2004) do not find a significant effect of training in developed countries, while Goedhuys (2007) does not find a significant relation between training and performance in Tanzania. However, we expect that the relation will be positive and significant in developing countries, because training of employees can compensate for the lower degree of education (Goedhuys and Srholec, 2015). Our results show that training fails to improve microfinance debtors' loan repayment rates. Those debtors endowed with skills related to business skills, i.e., general business planning, record keeping, financial management, market orientation do not repay their loans any better. The same holds for entrepreneurial skills. Those debtors with skills related to customer relations, risk tolerance, the entrepreneurs' innovativeness, pro-activeness and interpersonal relations do not show better repayment rates. In addition, our results show that training interventions fail to improve repayment rates. As holds for our results on the relevance of education, our observation that skills nor skills training interventions improve repayment rates is inconsistent with the human capital theory.

Business experience may be considered an important element of human capital. Bosma et al. (2004) find that prior experience of the business founder in the industry in which he starts his business improves business performance measures. Experience in activities relevant to business ownership also increases the firm's survival time. Other empirical studies, among others Smallbone and Welter (2001) and Hisrich and Drnovsek (2002), find that managerial competencies as measured by managerial experience, start-up experience and knowledge of the industry positively impact on the performance of new SMEs. We therefore expected business experience to improve microfinance debtor loan repayment rates. Our research findings are consistent with expectations. Those microfinance debtors endowed with 15 years of prior business experience pay their loans better than do less experienced debtors.

Our research findings are inconsistent with the human capital theory as proposed by Schultz (1961) and Becker (1976) in that we do not observe any impact of education nor skills training on repayment rates. Rather than education and skills training, we find that intensive monitoring of microbusiness entrepreneurs improves loan repayment rates. Our research findings are consistent with human capital theory in that we observe that those debtors endowed with prior business experience pay their loans better.

Most studies on the impact of entrepreneurship training on microbusiness performance and loan repayment rates rely on cross section data on respondents' self-evaluations. These studies 
cannot accurately assess the advantages of training programmes and leave the results unreliable (Martin et al., 2013). The present thesis provides a methodological contribution to the literature in that it examines the impact of training interventions on loan repayment rates by conducting a two-step longitudinal approach. We collect objective baseline data on repayment rates and, after having introduced training interventions, objective follow-up data on repayment rates for the very same debtors. As we compare objective baseline data with follow-up loan repayment data, we more accurately examine the impact of training on loan repayment rates of microfinance debtors.

\subsection{Implications for practitioners and policy makers}

We establish that CSR strategies that include social empowerment investments, skills training for microfinance debtors and debtor monitoring programmes help build public support for the MFI, improve opportunities to raise deposits and improve loan repayment rates. MFIs that adopt CSR strategies are expected to improve their sustainability, more than do MFIs that specialize in providing financial services only. We recommend considering CSR strategies a business opportunity rather than an expense.

We establish that those microfinance debtors that consider themselves endowed with entrepreneurial and business skills do not repay loans any better than those debtors lacking these skills. In addition, highly educated microfinance debtors do not repay their loans better than those with primary or secondary education only. We establish that business experience is the only constituent of human capital that is significantly related to loan repayment rates. We recommend policy makers to focus on those microbusiness entrepreneurs with significant business experience.

We establish that microfinance debtors do not agree on what skills they think are important for loan repayment probabilities. This result implies that every single microfinance debtor needs to acquire specific skills. We recommend training programmes to be tailored towards the needs of the individual microfinance debtor. MFI loan officers neither agree on the ranking of specific skills they think are important for microbusiness performance. We recommend MFIs to train loan officers to better understand the relevance of specific entrepreneurial and business skills for loan repayment probabilities. 
Our analyses show that intensive monitoring is key to loan repayment. Intensive monitoring proves equally effective for highly and poorly educated, experienced and unexperienced, female and male microfinance debtors. We recommend MFIs to consistently and intensively monitor their microfinance debtors.

\subsection{Limitations and recommendations for further research}

The main limitation of this study is its focus on a single MFI. The focus on uniCredit Ghana MFI may constrain generalisation of results and conclusions for all MFIs in developing countries. Further research on other MFIs in other developing countries is needed to validate our results and conclusions.

This study is the first to relate entrepreneurial and business skills of microbusiness entrepreneurs to loan repayment performance. As we do not establish any impact of selfevaluations on entrepreneurial and business skills on loan repayment rates, further research should focus on the skills of MFI loan officers, rather than microfinance debtors. Our results suggest that MFI loan officers should acquire skills to more accurately select viable loan applications and intensively monitor microfinance debtors.

As intensive monitoring programmes are labour intensive, further research should focus on cost-benefit analyses of intensive monitoring programmes. Expected improvements in repayment rates should be appraised and related to monitoring programmes investments. 


\section{References}

Agbeko, D., Blok, V., Omta, S. W. F. \& Van der Velde, G. (2016). Entrepreneurial and business skills and loan repayment rates of microfinance debtors in Ghana. Journal of Developmental Entrepreneurship, 21(4), 1-12. doi:10.1142/S1084946716500242.

Agbeko, D., Blok, V., Omta, S. W. F. \& Van der Velde, G. (2017a). Corporate social responsibility strategies adopted by micro finance institutions. A case study in corporate social responsibility. In S. O. Idowu \& S. Vertigans (Eds.), Corporate social responsibility in challenging times (pp. 247-258). Cham: Springer International Publishing. doi:10.1007/978-3-319-52839-7_13.

Agbeko, D., Blok, V., Omta, S. W. F. \& Van der Velde, G. (2017). The impact of training and monitoring on loan repayment of microfinance debtors in Ghana. Journal of Behavioural and Experimental Finance, 14, 23-29. doi.org/10.1016/j.jbef.2017.03.002.

Agbeko, D., Blok, V., Omta, S. W. F. \& Van der Velde, G. (2017b). Perception of microfinance debtors and loan officers on the relevance of business and entrepreneurial skills for loan repayment in Ghana. In C. Douglas, Y. Dong, H. Wenxuan \& S. Binayak (Eds.), Microfinance for entrepreneurial development: Sustainability and inclusion in emerging markets (forthcoming). Basingstoke: Palgrave Macmillan Publishing.

Aghion, P., Fally, T. \& Scarpetta, S. (2007). Credit constraints as a barrier to the entry and post-entry growth of firms. Economic Policy, 22(52), 732-779. doi:10.1111/j.14680327.2007.00190.x.

Alby, P., Auriol, E. \& Nguimkeu, P. (2013). Social barriers to entrepreneurship in Africa: The forced mutual help hypothesis. Unpublished manuscript. Retrieved from http://cepr.org/sites/default/files/AURIOL\%20-\%20sbea18Oct2013.pdf

Anthony, D. \& Horne, C. (2003). Gender and cooperation: Explaining loan repayment in micro-credit groups. Social Psychology Quarterly, 66(3), 293-302. doi:10.2307/1519827.

Appuhami, B. (2007). The impact of intellectual capital on investors' capital gains on shares: An empirical investigation of Thai banking, finance \& insurance sector. International Management Review, 3(2), 1-14.

Armendariz, B. \& Morduch, J. (2010). The economics of microfinance. Cambridge, MA: MIT Press. 
Armendáriz de Aghion, B. \& Morduch, J. (2000). Microfinance beyond group lending. Economics of Transition, 8(2), 401-420. doi:10.1111/1468-0351.00049.

Ashraf, N., Karlan, D. \& Yin, W. (2006). Tying Odysseus to the mast: Evidence from a commitment savings product in the Philippines. The Quarterly Journal of Economics, 121(2), 635-672.

Balogun, E. \& Alimi, A. (1988). Loan delinquency among small farmers in developing countries: A case study of the small-farmer credit programme in Lagos State of Nigeria. CBN Economic and Financial Review, 26(3), 67-72.

Banson, M. Y. (1997). The development of entrepreneurship in Ghana, opportunities for the tertiary graduate: A case study of UST graduates (Doctoral thesis, Kwame Nkrumah University of Science and Technology). Kabwe: Kwame Nkrumah University Press. Retrieved from http://ir.knust.edu.gh/xmlui/ handle/123456789/3076.

Baron, R. A. \& Ensley, M. D. (2006). Opportunity recognition as the detection of meaningful patterns: Evidence from comparisons of novice and experienced entrepreneurs. Management Science, 52(9), 1331-1344. doi:10.1287/mnsc.1060.0538.

Baron, R. A. \& Markman, G. D. (2003). Beyond social capital: The role of entrepreneurs' social competence in their financial success. Journal of Business Venturing, 18(1), 4160 .

Bastiaensen, J., Marchetti, P., Mendoza, R. \& Pérez, F. (2013). After the Nicaraguan nonpayment crisis: Alternatives to microfinance narcissism. Development and Change, 44(4), 861-885. doi:10.1111/dech.12046.

Baum, J. R. \& Locke, E. A. (2004). The relationship of entrepreneurial traits, skill, and motivation to subsequent venture growth. Journal of Applied Psychology, 89(4), 587598. doi:10.1037/0021-9010.89.4.587.

Becker, G.S. (1976). Human Capital. New York: National Bureau of Economic Research. Becker, G. S. (1993). Human Capital: A Theoretical and Empirical Analysis with Special Reference to Education (pp. 15-28). Chicago: The University of Chicago Press.

Behr, P., Entzian, A. \& Guettler, A. (2011). How do lending relationships affect access to credit and loan conditions in micro lending? Journal of Banking \& Finance, 35(8), 2169-2178.

Bhatt, N. \& Tang, S. Y. (2001). Delivering microfinance in developing countries: Controversies and policy perspectives. Policy Studies Journal, 29(2), 319-333. 
Bichanga, W. \& Aseyo, L. (2013). Causes of loan default within micro finance institutions in Kenya. Interdisciplinary Journal of Contemporary Research in Business, 4(12), 316335.

Bloem, A. \& Goerter, C. (2001). The macroeconomic statistical treatment of non-performing loans (STD/NA200224). Washington: Statistics Department of the IMF. Retrieved from the Organisation for Economic Co-operation and Development website: www.oecd.org/std/na/1950149.doc.

Bosma, N., Van Praag, M., Thurik, R. \& De Wit, G. (2004). The value of human and social capital investments for the business performance of startups. Small Business Economics, 23(3), 227-236.

Bowman, E. H. \& Haire, M. (1975). A strategic posture toward corporate social responsibility. California Management Review, 18(2), 49-58.

Brammer, S. \& Millington, A. (2008). Does it pay to be different? An analysis of the relationship between corporate social and financial performance. Strategic Management Journal, 29(12), 1325-1343.

Brozova, H., Subrt, T. \& Vorlickova, L. (2008). The system approach to knowledge creation, sharing and utilisation in managerial competency models. International Journal of Learning and Intellectual Capital, 6(1-2), 103-116.

Bruderl, J., Preisendorfer, P. \& Ziegler, R. (1992). Survival Chances of Newly Founded Business Organizations. American Sociological Review, 57(2), 227-242.

Caloghirou, Y., Kastelli, I. \& Tsakanikas, A. (2004). Internal capabilities and external knowledge sources: complements or substitutes for innovative performance? Technovation, 24(1), 29-39.

Carroll, A. B. (1991). The pyramid of corporate social responsibility: Toward the moral management of organizational stakeholders. Business Horizons, 34(4), 39-48.

Carroll, A. B. \& Shabana, K. M. (2010). The business case for corporate social responsibility: A review of concepts, research and practice. International Journal of Management Reviews, 12(1), 85-105.

Chandler, G. N. \& Jansen, E. (1992). The founder's self-assessed competence and venture performance. Journal of Business Venturing, 7(3), 223-236. doi:10.1016/08839026(92)90028-p.

Chen, C. C., Greene, P. G. \& Crick, A. (1998). Does entrepreneurial self-efficacy distinguish entrepreneurs from managers? Journal of Business Venturing, 13(4), 295-316. doi:10.1016/s0883-9026(97)00029-3. 
Chen, K. C., Chen, Z. \& Wei, K. J. (2009). Legal protection of investors, corporate governance, and the cost of equity capital. Journal of Corporate Finance, 15(3), 273289. doi:10.1016/j.jcorpfin.2009.01.001.

Chen, Y., Guo, R.-J. \& Huang, R.-L. (2009). Two stages credit evaluation in bank loan appraisal. Economic Modelling, 26(1), 63-70. doi:10.1016/j.econmod.2008.05.008.

Cheng, B., Ioannou, I. \& Serafeim, G. (2014). Corporate social responsibility and access to finance. Strategic Management Journal, 35(1), 1-23. doi:10.2139/ssrn.1847085.

Cohen, W. \& Levinthal, D. (1990). Absorptive capacity: A new perspective on learning and innovation. Administrative Science Quarterly, 35, 128-152.

Cook, P. (2001). Finance and small and medium-sized enterprise in developing countries. Journal of Developmental Entrepreneurship, 6(1), 17-40.

Crane, A., Matten, D., Moon, J. \& Moon, J. (2008). Corporations and citizenship. Cambridge: University Press Cambridge.

Cowen, S. S., Ferreri, L. B. \& Parker, L. D. (1987). The impact of corporate characteristics on social responsibility disclosure: A typology and frequency-based analysis. Accounting, Organizations and Society, 12(2), 111-122.

Dakhli, M. \& De Clercq, D. (2004). Human capital, social capital, and innovation: a multicountry study. Entrepreneurship \& Regional Development, 16(2), 107-128.

Dhaliwal, D. S., Li, O. Z., Tsang, A. \& Yang, Y. G. (2011). Voluntary nonfinancial disclosure and the cost of equity capital: The initiation of corporate social responsibility reporting. The Accounting Review, 86(1), 59-100.

Dhanaraj, C., Lyles, M., Steensma, K. \& Tihanyi, L. (2004). Managing tacit and explicit knowledge transfer in IJVs: the role of relational embeddedness and the impact on performance. Journal of International Business Studies, 35, 428-442.

Dumas, C. (2001). Micro enterprise training for low-income women: The case of the Community Entrepreneurs Programme. Journal of Entrepreneurship, 10(1), 17-42. doi:10.1177/097135570101000102.

Echtner, C. M. (1995). Entrepreneurial training in developing countries. Annals of Tourism Research, 22(1), 119-134. doi:10.1016/0160-7383(94)00065-z.

Edgcomb, E. L. (2002). What makes for effective microenterprise training? Journal of Microfinance/ESR Review, 4(1), 99-114.

Ekpe, I., Mat, N. B. \& Razak, R. C. (2010). The effect of microfinance factors on women entrepreneurs' performance in Nigeria: A conceptual framework. International Journal of Business and Social Science, 1(2), 255-263. 
Elaine, E. \& Barton, L. (1998). Social intermediation and microfinance programmes: A literature review. Bethesda: Microenterprises Best Practices. Retrieved from http://pdf.usaid.gov/pdf_docs/Pnacd060.pdf.

Field, A. (2009). Discovering statistics using SPSS (3rd ed.). Thousand Oaks, CA: SAGE Publications Ltd.

Field, E. \& Pande, R. (2008). Repayment frequency and default in microfinance: Evidence from India. Journal of the European Economic Association, 6(2-3), 501-509. doi:10.1162/jeea.2008.6.2-3.501.

Ganotakis, P. \& Love, J. (2011). R\&D, product innovation, and exporting: evidence from UK new technology based firms. Oxford Economic Papers, 63(2), 279-306,

Gatewood, E. J., Shaver, K. G. \& Gartner, W. B. (1995). A longitudinal study of cognitive factors influencing start-up behaviors and success at venture creation. Journal of Business Venturing, 10(5), 371-391. doi:10.1016/0883-9026(95)00035-7.

Gimeno, J., Folta, T, Cooper, A. \& Woo, C. (1997). Survival of the Fittest? Entrepreneurial Human Capital and the Persistence of Underperforming Firms. Administrative Science Quarterly, 42(4), 750-783.

Gird, A. \& Bagraim, J. J. (2008). The theory of planned behaviour as predictor of entrepreneurial intent amongst final-year university students. South African Journal of Psychology, 38(4), 711-724. doi:10.1177/008124630803800410.

Godquin, M. (2004). Microfinance repayment performance in Bangladesh: How to improve the allocation of loans by MFIs. World Development, 32(11), 1909-1926. doi:10.1016/j.worlddev.2004.05.011.

Goedhuys, M. (2007). Learning, product innovation, and firm heterogeneity in developing countries; Evidence from Tanzania. Industrial and Corporate Change, 16(2), 269-292.

Goedhuys, M. \& Srholec, M. (2015). Technological capabilities, institutions and firm productivity: a multilevel study. The European Journal of Development Research, 27(1), 122-139.

Gray, B., Gash, M., Reeves, S. \& Crookston, B. (2011). Microfinance: A sustainable platform for non-financial services. In T. Wouters (Ed.), Progress in Economics Research (pp. 163-182). Hauppauge, NY: Nova Science Publishers.

Gutierrez-Nieto, B., Serrano-Cinca, C. \& Molinero, C. M. (2007). Microfinance institutions and efficiency. Omega, 35(2), 131-142. doi:10.1016/j.omega.2005.04.001. 
Hessels, J. \& Terjesen, S. (2008). SME Choice of Direct and Indirect Export Modes:

Resource Dependency and Institutional Theory Perspectives. Zoetermeer: Netherlands Ministry of Economic Affairs.

Hisrich, R. D. \& Drnovsek, M. (2002). Entrepreneurship and small business research-a European perspective. Journal of Small Business and Enterprise Development, 9(2), $172-222$.

Hutcheson, G. D. \& Sofroniou, N. (1999). The multivariate social scientist: Introductory statistics using generalized linear models. Thousand Oaks, CA: SAGE Publications Ltd.

Idris, A. J. \& Agbim, K. C. (2015a). Effect of social capital on poverty alleviation: A study of women entrepreneurs in Nasarawa State, Nigeria. Journal of Research in National Development, 13(1), 208-222.

Idris, A. J. \& Agbim, K. C. (2015b). Micro-credit as a strategy for poverty alleviation among women entrepreneurs in Nasarawa State, Nigeria. Journal of Business Studies Quarterly, 6(3), 122-143.

Joakim, E. P. \& Wismer, S. K. (2015). Livelihood recovery after disaster. Development in Practice, 25(3), 401-418. doi:10.1080/09614524.2015.1020764.

Kabeer, N. (2001). Conflicts over credit: Re-evaluating the empowerment potential of loans to women in rural Bangladesh. World Development, 29(1), 63-84. doi:10.1016/s0305$750 x(00) 00081-4$.

Karlan, D. \& Valdivia, M. (2011). Teaching entrepreneurship: Impact of business training on microfinance clients and institutions. Review of Economics and Statistics, 93(2), 510527. doi:10.1162/Rest_a_00074.

Karnani, A. G. (2007). Employment, not microcredit, is the solution. Ross School of Business Working Paper Series, 1065, 1-14. doi:10.2139/ssrn.962941.

Kevane, M. \& Wydick, B. (2001). Microenterprise lending to female entrepreneurs: Sacrificing economic growth for poverty alleviation? World Development, 29(7), 1225-1236. doi:10.1016/s0305-750x(01)00032-8.

Kitzinger, J. (1994). The methodology of focus groups: The importance of interaction between research participants. Sociology of Health \& Illness, 16(1), 103-121. doi:10.1111/1467-9566.ep11347023.

Kitzinger, J. (1995). Qualitative research. Introducing focus groups. BMJ: British Medical Journal, 311(7000), 299-302. doi:10.1136/bmj.311.7000.299. 
Kohansal, M. R. \& Mansoori, H. (2009, October). Factors affecting on loan repayment performance of farmers in Khorasan-Razavi province of Iran. Paper presented at the Conference on International Research on Food Security, Natural Resource Management and Rural Development, Hamburg.

Kraiger, K., Ford, J. K. \& Salas, E. (1993). Application of cognitive, skill-based, and affective theories of learning outcomes to new methods of training evaluation. Journal of Applied Psychology, 78(2), 311-328. doi:10.1037/0021-9010.78.2.311.

Kumar, K., Roberts, C., Rothnie, I., Du Fresne, C. \& Walton, M. (2009). Experiences of the multiple mini-interview: A qualitative analysis. Medical Education, 43(4), 360-367. doi:10.1111/j.1365-2923.2009.03291.x.

Kuzilwa, J. A. (2005). The Role of Credit for Small Business Success A Study of the National Entrepreneurship Development Fund in Tanzania. Journal of Entrepreneurship, 14(2), 131-161.

Kwasi Buame, S. (1996). Entrepreneurship: A contextual perspective. discourses and praxis of entrepreneurial activities within the institutional context of Ghana. Lund: Lund University Press.

Lans, T., Blok, V. \& Gulikers, J. (2015). Show me your network and I'll tell you who you are: Social competence and social capital of early-stage entrepreneurs. Entrepreneurship \& Regional Development, 27(7-8), 458-473. doi:10.1080/08985626.2015.1070537.

Ledgerwood, J. (1999). Microfinance handbook: An institutional and financial perspective. Washington, DC: World Bank.

Lefebvre, E. \& Lefebvre, L. (2002). Innovative capabilities as determinants of export performance and behaviour: A longitudinal study of manufacturing SMEs. In A. Kleinknecht \& P. Mohnen (Eds.), Innovation and Firm Performance (pp. 281-309). UK: Palgrave Macmillan.

Leitao, J. \& Franco, M. (2008). Individual entrepreneurship capacity and performance of SMEs. Lisbon: Technical university of Lisbon.

Lensink, R., Mersland, R. \& Nhung, V. T. H. (2011, June). Should microfinance institutions specialize in financial services. Paper presented at the Second International Research Conference on Microfinance, Groningen.

Lindell, M. K. \& Whitney, D. J. (2001). Accounting for common method variance in crosssectional research designs. Journal of Applied Psychology, 86(1), 114-121.

Mader, P. (2013). Rise and fall of microfinance in India: The Andhra Pradesh crisis in perspective. Strategic Change, 22(1-2), 47-66. doi:10.1002/jsc.1921. 
Mahemba, C. \& Bruijn, E. (2003). Innovation activities by small and medium-sized manufacturing enterprises in Tanzania. Creativity and Innovation Management, 12(3), 162-173.

Mano, Y., Iddrisu, A., Yoshino, Y. \& Sonobe, T. (2012). How can micro and small enterprises in Sub-Saharan Africa become more productive? The impacts of experimental basic managerial training. World Development, 40(3), 458-468. doi:10.1016/j.worlddev.2011.09.013.

Martin, B. C., McNally, J. J. \& Kay, M. J. (2013). Examining the formation of human capital in entrepreneurship: A meta-analysis of entrepreneurship education outcomes. Journal of Business Venturing, 28(2), 211-224. doi:10.1016/j.jbusvent.2012.03.002.

Martin, G. \& Staines, H. (2008). Managerial competencies in Small firm. A Scoping Study. Burundi: Acts Press.

Marvel, M. \& Lumpkin, G. (2007). Technology entrepreneurs' human capital and its effects on innovation radicalness. Entrepreneurship Theory and Practice, 31(6), 807-828.

McKenzie, D. \& Woodruff, C. (2013). What are we learning from business training and entrepreneurship evaluations around the developing world? World Bank Research Observer, 29(1), 48-82.

Mensah, C., Raphael, G., Dorcas, O. \& Kwadwo, B. Y. (2013). The relationship between loan default and repayment schedule in microfinance institutions in Ghana: A case study of Sinapi Aba Trust. Research Journal of Finance and Accounting, 4(19), 165-175.

Moskowitz, M. (1972). Choosing socially responsible stocks. Business and Society Review, $1(1), 71-75$.

Mulugetta, A. (2010). An assessment of loan provision and causes for default: A case study of Wisdom (Thesis Mekelle University). Mekelle: Mekelle University.

Mutisya, E. \& Yarime, M. (2014). Microcredit for the development of the bottom of the pyramid segment: Impact of access to financial services on microcredit clients, institutions and urban sustainability. (Working Paper Series No. 199). Abidjan: African Development bank. Retrieved from African Development Bank Group website: https://www.afdb.org/fileadmin/uploads/afdb/Documents/Publications/ Working_Paper_199.

Nelson, R. \& Phelps, E. (1966). Investment in humans, technological diffusion, and economic growth. The American Economic Review, 56(1/2), 69-75.

Newman, A., Schwarz, S. \& Borgia, D. (2014). How does microfinance enhance entrepreneurial outcomes in emerging economies? The mediating mechanisms of 
psychological and social capital. International Small Business Journal, 32(2), 158179. doi:10.1177/0266242613485611.

Ntiamoah, E. B., Oteng, E., Opoku, B. \& Siaw, A. (2014). Loan default rate and its impact on profitability in financial institutions. Research Journal of Finance and Accounting, 5(14), 67-72.

Olomola, A. (2000, April). Determinants of the smallholder loan repayment performance: Evidence from the Nigerian microfinance system. Paper presented at the conference Opportunities in Africa: Micro-evidence on Firms and Households, Oxford.

Oosterbeek, H., Van Praag, M. \& Ijsselstein, A. (2010). The impact of entrepreneurship education on entrepreneurship skills and motivation. European Economic Review, 54(3), 442-454. doi:10.1016/j.euroecorev.2009.08.002.

Orford, J., Herrington, M. \& Wood, E. (2004). Global entrepreneurship monitor: South African report. Cape Town: UCT Graduate School of Business.

Otero-Neira, C., Arias, M. J. F. \& Lindman, M. T. (2013). Market orientation and entrepreneurial proclivity: Antecedents of innovation. Global Business Review, 14(3), 385-395. doi:10.1177/0972150913496719.

Parket, I. R. \& Eilbirt, H. (1975). The practice of business social responsibility: The underlying factors. Business Horizons, 18(4), 5-10. doi:10.1016/0007-6813(75)900191.

Ployhart, R. E. \& Moliterno, T. P. (2011). Emergence of the human capital resource: A multilevel model. Academy of Management Review, 36(1), 127-150. doi:10.5465/amr.2009.0318.

Pronyk, P. M., Kim, J. C., Abramsk, T., Phetla, G., Hargreaves, J. R., Morison, L. A., Porter, J. D. H. (2008). A combined microfinance and training intervention can reduce HIV risk behaviour in young female participants. AIDS, 22(13), 1659-1665. doi:10.1097/qad.0b013e328307a040.

Rahman, A. (1999). Women and microcredit in rural Bangladesh: Anthropological study of the rhetoric and realities of Grameen Bank lending. Boulder, CO: Westview Press.

Ribando, J. M. \& Bonne, G. (2010). A new quality factor: Finding alpha with ASSET4 ESG data (Starmine Research Note). New York: Thomson Reuters. Retrieved from Thomson Reuters website: https://www.thomsonreuters.com/content/dam/openweb/documents/pdf/tr-comfinancial/report/starmine-quant-research-note-on-asset4-data.pdf . 
Ridgeway, C. L. \& Smith-Lovin, L. (1999). The gender system and interaction. Annual Review of Sociology, 25(4), 191-216. doi:10.1146/annurev.soc.25.1.191.

Robinson, M. S. (2002). The microfinance revolution: Lessons from Indonesia (The World Bank Report No. 23250). Washington: The World Bank. Retrieved from The World Bank website:

http://documents.worldbank.org/curated/en/524471468044690635/lessons-fromIndonesia.

Robson, J., Miller, A., Idrobo, C., Burlando, C., Deutsch, N., Kocho-Schellenberg, J., Pengelly, R. \& Turner, K. (2009). Building communities of learning: Indigenous ways of knowing in contemporary natural resources and environmental management. Journal of the Royal Society of New Zealand, 39(4), 173-177.

Schneider, M., Schulze-Bentrop, C. \& Paunescu, M. (2010). Mapping the institutional capital of high-tech firms: A fuzzy-set analysis of capitalist variety and export performance. Journal of International Business Studies, 41(2), 246-266.

Schultz, T.W. (1961). Investment in Human Capital. American Economic Review, 51(1), 1-17. Seuneke, P., Lans, T. \& Wiskerke, J. S. (2013). Moving beyond entrepreneurial skills: Key factors driving entrepreneurial learning in multifunctional agriculture. Journal of Rural Studies, 32(6), 208-219. doi:10.1016/j.jrurstud.2013.06.001.

Sharma, M. \& Zeller, M. (1997). Repayment performance in group-based credit programs in Bangladesh: An empirical analysis. World Development, 25(10), 1731-1742. doi:10.1016/s0305-750x(97)00063-6.

Silverman, D. (2010). Qualitative Research (3rd ed.). Thousand Oaks, CA: SAGE Publications Ltd.

Sjauw-Koen-Fa, A. R., Blok, V. \& Omta, S. O. (2016). Critical success factors for smallholder inclusion in high value-adding supply chains by food \& agribusiness multinational enterprises. International Food and Agribusiness Management Review, 19(1), 83-112.

Smallbone, D. \& Welter, F. (2001). The distinctiveness of entrepreneurship in transition economies. Small Business Economics, 16(4), 249-262.

Smith, E. \& Perks, S. (2006). Training interventions needed for developing black microentrepreneurial skills in the informal sector: A qualitative perspective. SA Journal of Human Resource Management, 4(1), 17-26. doi:10.4102/sajhrm.v4i1.85.

Solomon, R. C. (1985). It's good business: Ethics and free enterprise for the new millennium. Lanham, MD: Rowman \& Littlefield. 
Tang, Z. \& Tang, J. (2012). Stakeholder-firm power difference, stakeholders' CSR orientation, and SMEs' environmental performance in China. Journal of Business Venturing, 27(4), 436-455. doi:10.1016/j.jbusvent.2011.11.007.

Ucbasaran, D., Westhead, P. \& Wright, M. (2008). Opportunity identification and pursuit: Does an entrepreneur's human capital matter? Small Business Economics, 30(2), 153173. doi:10.1007/s11187-006-9020-3

Vance, S. C. (1975). Are socially responsible corporations good investment risks. Management Review, 64(8), 19-24.

Van Dyk, P. S., Nel, P. S. \& van Zyl Loedolff, P. (1992). Training management: A multidisciplinary approach to human resources development in Southern Africa. Gauteng: Southern Book Publishers.

Verhees, F. J., Lans, T. \& Verstegen, J. A. (2012). The influence of market and entrepreneurial orientation on strategic marketing choices: The cases of Dutch farmers and horticultural growers. Journal on Chain and Network Science, 12(2), 167-179. doi:10.3920/jens2012.x011.

Viera, A. J. \& Garrett, J. M. (2005). Understanding interobserver agreement: The kappa statistic. Family Medicine, 37(5), 360-363.

Wichterich, C. (2012). The other financial crisis: Growth and crash of the microfinance sector in India. Development, 55(3), 406-412. doi:10.1057/dev.2012.58.

Wiklund, J., Patzelt, H. \& Shepherd, D. A. (2009). Building an integrative model of small business growth. Small Business Economics, 32(4), 351-374. doi:10.1007/s11187-0079084-8.

Yunus, M. (1999). The Grameen Bank. Scientific American, 281(5), 114-119. doi:10.1038/scientificamerican1199-114. 


\section{Appendix A Constructs and measurements}

Entrepreneurial and business skills in relation to loan repayment rates of Microfinance clients in Ghana.

What is your gender?

male / female

What is your age?

$<20$ years 20-30 years 31-39 years $40-50$ years $>50$ years

What is your highest level of education?

Primary education / Secondary education / Tertiary education

When did you start your business?

$<5$ years ago $\quad 5-10$ years ago $\quad 11-14$ years ago $\quad 15-20$ years ago $>20$ years ago

\begin{tabular}{|l|l|l|l|l|}
\hline Construct & Operationalisation & Literature & Items/measurements & Questions \\
\hline Business operations skills & General Business planning & $\begin{array}{l}\text { Smith \& Perks (2006), Van Dyk et } \\
\text { al. (1992) }\end{array}$ & Short-term planning & $\begin{array}{l}\text { A1. You plan your bussiness } \\
\text { acivities by documenting what to } \\
\text { do: 7 pt. likert scale ranging from } \\
\text { strongly disagree to strongly agree }\end{array}$ \\
\hline & & $\begin{array}{l}\text { Smith \& Perks (2006), Van Dyk et } \\
\text { al. (1992) }\end{array}$ & Budgeting & $\begin{array}{l}\text { A2. You budget your purchases by } \\
\text { buying your stock in bulk (on } \\
\text { wholesale basis): 7 pt. likert scale } \\
\text { ranging from strongly disagree to } \\
\text { strongly agree }\end{array}$ \\
\hline & & $\begin{array}{l}\text { Smith \& Perks (2006), Van Dyk et } \\
\text { al. (1992) }\end{array}$ & Handling security & $\begin{array}{l}\text { A3. You anticipate or foresee the } \\
\text { possibility of theft in your business } \\
\text { eg. loss of stock or cash: 7 pt. likert } \\
\text { scale ranging from strongly } \\
\text { disagree to strongly agree }\end{array}$ \\
\hline
\end{tabular}


Appendix A Constructs and measurements - continued

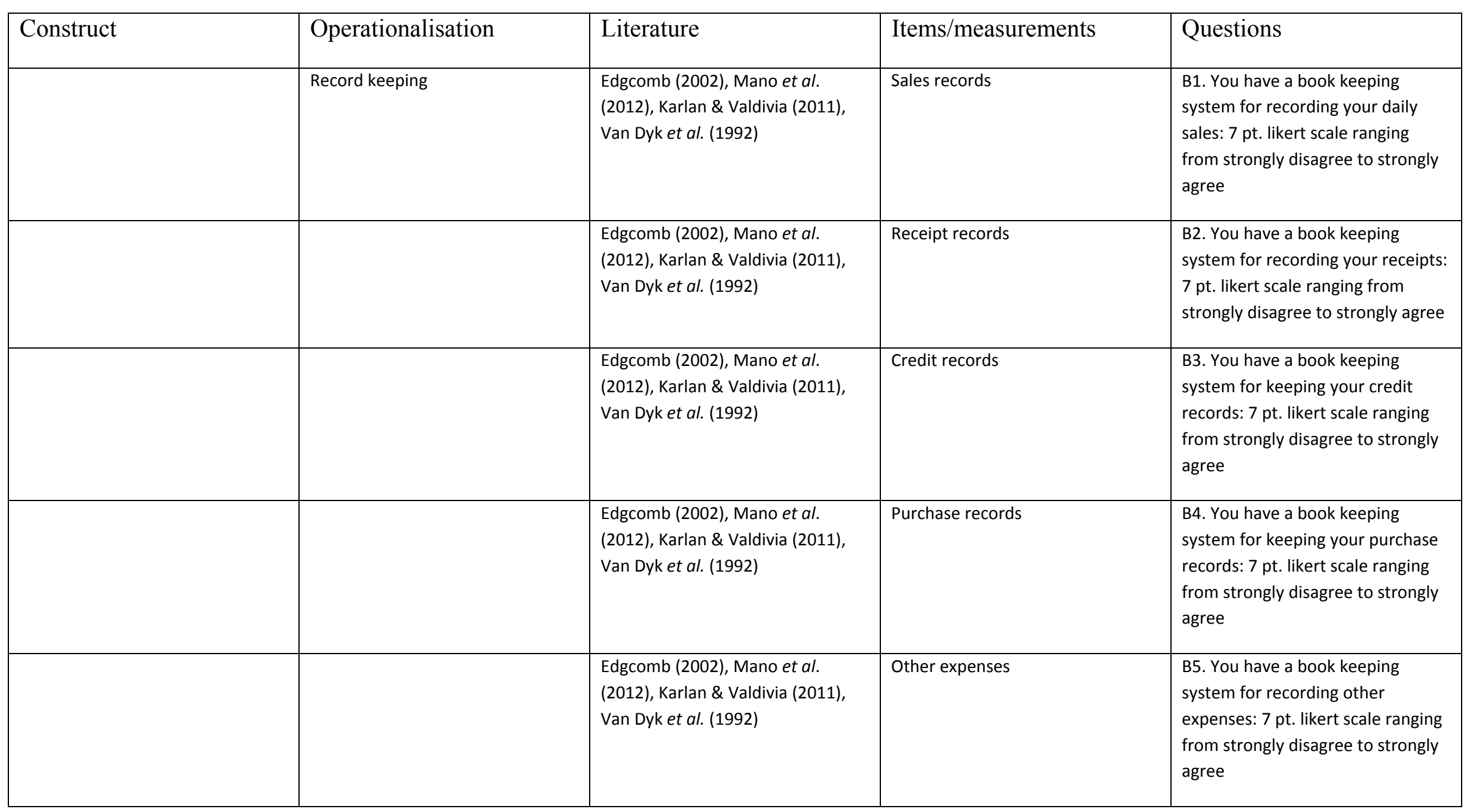


Appendix A Constructs and measurements - continued

\begin{tabular}{|c|c|c|c|c|}
\hline Construct & Operationalisation & Literature & Items/measurements & Questions \\
\hline & & $\begin{array}{l}\text { Edgcomb (2002), Mano et al. } \\
\text { (2012), Karlan \& Valdivia (2011), } \\
\text { Van Dyk et al. (1992) }\end{array}$ & Stock taking & $\begin{array}{l}\text { B. } 6 \text { You take stock of your items in } \\
\text { the shop: } 7 \text { pt. likert scale ranging } \\
\text { from strongly disagree to strongly } \\
\text { agree : }\end{array}$ \\
\hline & & $\begin{array}{l}\text { Edgcomb (2002), Mano et al. } \\
\text { (2012), Karlan \& Valdivia (2011), } \\
\text { Van Dyk et al. (1992) }\end{array}$ & Filing purchases receipts & $\begin{array}{l}\text { B.7 You file your purchases } \\
\text { receipts: } 7 \text { pt. likert scale ranging } \\
\text { from strongly disagree to strongly } \\
\text { agree }\end{array}$ \\
\hline & & $\begin{array}{l}\text { Edgcomb (2002), Mano et al. } \\
\text { (2012), Karlan \& Valdivia (2011), } \\
\text { Van Dyk et al. (1992) }\end{array}$ & Filing sales receipts & $\begin{array}{l}\text { B.8 You file your sales receipts: } 7 \\
\text { pt. likert scale ranging from } \\
\text { strongly disagree to strongly agree }\end{array}$ \\
\hline & & $\begin{array}{l}\text { Edgcomb (2002), Mano et al. } \\
\text { (2012), Karlan \& Valdivia (2011), } \\
\text { Van Dyk et al. (1992) }\end{array}$ & Filing invoices & $\begin{array}{l}\text { B.9 You file your invoices: } 7 \mathrm{pt} \text {. } \\
\text { likert scale ranging from strongly } \\
\text { disagree to strongly agree }\end{array}$ \\
\hline & Financial Management & $\begin{array}{l}\text { Edgcomb (2002), Mano et al. } \\
\text { (2012), Karlan \& Valdivia (2011), } \\
\text { Smith \& Perks (2006) }\end{array}$ & Sources of finance & $\begin{array}{l}\text { C.1 You believe that you will get } \\
\text { finance from other MFIs if you } \\
\text { apply: } 7 \text { pt. likert scale ranging } \\
\text { from strongly disagree to strongly } \\
\text { agree }\end{array}$ \\
\hline & & $\begin{array}{l}\text { Edgcomb (2002), Mano et al. } \\
\text { (2012), Karlan \& Valdivia (2011), } \\
\text { Smith \& Perks (2006) }\end{array}$ & Fixed salaries & $\begin{array}{l}\text { C2. You pay yourself a fixed salary: } \\
7 \text { pt. likert scale ranging from } \\
\text { strongly disagree to strongly agree }\end{array}$ \\
\hline & & $\begin{array}{l}\text { Edgcomb (2002), Mano et al. } \\
\text { (2012), Karlan \& Valdivia (2011), } \\
\text { Smith \& Perks (2006) }\end{array}$ & Caculating Profits & $\begin{array}{l}\text { C3. You calculate your profits: } 7 \mathrm{pt} \text {. } \\
\text { likert scale ranging from strongly } \\
\text { disagree to strongly agree }\end{array}$ \\
\hline
\end{tabular}


Appendix A Constructs and measurements - continued

\begin{tabular}{|c|c|c|c|c|}
\hline Construct & Operationalisation & Literature & Items/measurements & Questions \\
\hline & Interpersonal Relations & $\begin{array}{l}\text { Smith \& Perks (2006), Van Dyk et } \\
\text { al. (1992) }\end{array}$ & Employees rewards & $\begin{array}{l}\text { D1. You provide rewards for jobs } \\
\text { well done: } 7 \mathrm{pt} \text {. likert scale ranging } \\
\text { from strongly disagree to strongly } \\
\text { agree }\end{array}$ \\
\hline & & $\begin{array}{l}\text { Smith \& Perks (2006), Van Dyk et } \\
\text { al. (1992) }\end{array}$ & Employee sanctions & $\begin{array}{l}\text { D2. You sanction employees for } \\
\text { work not done well: } 7 \mathrm{pt} \text {. likert } \\
\text { scale ranging from strongly } \\
\text { disagree to strongly agree }\end{array}$ \\
\hline & & $\begin{array}{l}\text { Smith \& Perks (2006), Van Dyk et } \\
\text { al. (1992) }\end{array}$ & Employee procedures & $\begin{array}{l}\text { D2. You create clear working } \\
\text { schedules and procedures for your } \\
\text { employees: } 7 \text { pt. likert scale } \\
\text { ranging from strongly disagree to } \\
\text { strongly agree }\end{array}$ \\
\hline & Customer Relations & $\begin{array}{l}\text { Smith \& Perks (2006), Van Dyk et } \\
\text { al. (1992) }\end{array}$ & Dealing with customers & $\begin{array}{l}\text { E1. Keeping a good relationship } \\
\text { with your customers is important: } \\
7 \text { pt. likert scale ranging from } \\
\text { strongly disagree to strongly agree }\end{array}$ \\
\hline & & $\begin{array}{l}\text { Smith \& Perks (2006), Van Dyk et } \\
\text { al. (1992) }\end{array}$ & Listening & $\begin{array}{l}\text { E2. Listening to the concerns of } \\
\text { your customers and using it to } \\
\text { improve on your business is } \\
\text { important: } 7 \text { pt. likert scale ranging } \\
\text { from strongly disagree to strongly } \\
\text { agree }\end{array}$ \\
\hline
\end{tabular}




\section{Appendix A Constructs and measurements - continued}

\begin{tabular}{|c|c|c|c|c|}
\hline Construct & Operationalisation & Literature & Items/measurements & Questions \\
\hline & & $\begin{array}{l}\text { Smith \& Perks (2006), Van Dyk et } \\
\text { al. (1992) }\end{array}$ & Understanding customer needs & $\begin{array}{l}\text { E3. Understanding the needs of } \\
\text { your customers and trying to meet } \\
\text { these is important: } 7 \mathrm{pt} \text {. likert scale } \\
\text { ranging from strongly disagree to } \\
\text { strongly agree }\end{array}$ \\
\hline \multirow[t]{5}{*}{ Entrepreneurial skills } & Risk taking & $\begin{array}{l}\text { Chen et al. (1998), Oosterbeek et } \\
\text { al. (2010), Verhees et al. (2012) }\end{array}$ & Taking calculated risks & $\begin{array}{l}\text { F1. You take calculated risks in } \\
\text { your business: } 7 \mathrm{pt} \text {. likert scale } \\
\text { ranging from strongly disagree to } \\
\text { strongly agree }\end{array}$ \\
\hline & & $\begin{array}{l}\text { Chen et al. (1998), Oosterbeek et } \\
\text { al. (2010), Verhees et al. (2012) }\end{array}$ & $\begin{array}{l}\text { Making decisions under pressure } \\
\text { and risks }\end{array}$ & $\begin{array}{l}\text { F2. You make decisions under } \\
\text { pressure and risks: } 7 \mathrm{pt.} \text { likert scale } \\
\text { ranging from strongly disagree to } \\
\text { strongly agree }\end{array}$ \\
\hline & & $\begin{array}{l}\text { Chen et al. (1998), Oosterbeek et } \\
\text { al. (2010), Verhees et al. (2012) }\end{array}$ & $\begin{array}{l}\text { Taking responsibility for ideas and } \\
\text { decisions }\end{array}$ & $\begin{array}{l}\text { F3. You take responsibility for } \\
\text { ideas and risks you take: } 7 \mathrm{pt.} \text { likert } \\
\text { scale ranging from strongly } \\
\text { disagree to strongly agree }\end{array}$ \\
\hline & & $\begin{array}{l}\text { Chen et al. (1998), Oosterbeek et } \\
\text { al. (2010), Verhees et al. (2012) }\end{array}$ & $\begin{array}{l}\text { Working under pressure and } \\
\text { conflicts }\end{array}$ & $\begin{array}{l}\text { F4. You work under pressure and } \\
\text { conflicts: } 7 \text { pt. likert scale ranging } \\
\text { from strongly disagree to strongly } \\
\text { agree }\end{array}$ \\
\hline & Innovativeness & $\begin{array}{l}\text { Chen et al. (1998), Verhees et al. } \\
\text { (2012) }\end{array}$ & New venturing and new ideas & $\begin{array}{l}\text { G1. You introduced and used new } \\
\text { ideas over the past } 5 \text { years in your } \\
\text { business: } 7 \text { pt. likert scale ranging } \\
\text { from strongly disagree to strongly } \\
\text { agree }\end{array}$ \\
\hline
\end{tabular}


Appendix A Constructs and measurements - continued

\begin{tabular}{|c|c|c|c|c|}
\hline Construct & Operationalisation & Literature & Items/measurements & Questions \\
\hline & & $\begin{array}{l}\text { Chen et al. (1998), Verhees et al. } \\
\text { (2012) }\end{array}$ & New products and services & $\begin{array}{l}\text { G2. You introduced and used new } \\
\text { products and services over the } \\
\text { past } 5 \text { years in your business: } 7 \mathrm{pt} \text {. } \\
\text { likert scale ranging from strongly } \\
\text { disagree to strongly agree }\end{array}$ \\
\hline & & $\begin{array}{l}\text { Chen et al. (1998), Verhees et al. } \\
\text { (2012) }\end{array}$ & $\begin{array}{l}\text { New markets and geographical } \\
\text { territories }\end{array}$ & $\begin{array}{l}\text { G3. You have explored new } \\
\text { markets and geographical } \\
\text { territories over the past } 5 \text { years: } 7 \\
\text { pt. likert scale ranging from } \\
\text { strongly disagree to strongly agree }\end{array}$ \\
\hline & & $\begin{array}{l}\text { Chen et al. (1998), Verhees et al. } \\
\text { (2012) }\end{array}$ & New methods of production & $\begin{array}{l}\text { G4. You have applied new } \\
\text { methods of production in your } \\
\text { business over the past } 5 \text { years: } 7 \\
\text { pt. likert scale ranging from } \\
\text { strongly disagree to strongly agree }\end{array}$ \\
\hline & & $\begin{array}{l}\text { Chen et al. (1998), Verhees et al. } \\
\text { (2012) }\end{array}$ & New methods of marketing & $\begin{array}{l}\text { G5. You have applied new } \\
\text { marketing strategies in your } \\
\text { business over the past } 5 \text { years: } 7 \\
\text { pt. likert scale ranging from } \\
\text { strongly disagree to strongly agree }\end{array}$ \\
\hline & & $\begin{array}{l}\text { Chen et al. (1998), Verhees et al. } \\
\text { (2012) }\end{array}$ & New methods of management & $\begin{array}{l}\text { G6. You have applied new } \\
\text { management styles in your } \\
\text { business over the past } 5 \text { years: } 7 \\
\text { pt. likert scale ranging from } \\
\text { strongly disagree to strongly agree }\end{array}$ \\
\hline
\end{tabular}




\section{Appendix A Constructs and measurements - continued}

\begin{tabular}{|c|c|c|c|c|}
\hline Construct & Operationalisation & Literature & Items/measurements & Questions \\
\hline & Pro-activeness & Verhees et al. (2012) & Willingness to start new activities & $\begin{array}{l}\text { H1. You are willing to start } \\
\text { business activities that your } \\
\text { competitors have not started yet: } \\
7 \text { pt. likert scale ranging from } \\
\text { strongly disagree to strongly agree }\end{array}$ \\
\hline & & Verhees et al. (2012) & $\begin{array}{l}\text { First to respond to new } \\
\text { opportunities }\end{array}$ & $\begin{array}{l}\text { H2. You are the first to respond to } \\
\text { new business opportunities: } 7 \mathrm{pt.} \\
\text { likert scale ranging from strongly } \\
\text { disagree to strongly agree }\end{array}$ \\
\hline & & Verhees et al. (2012) & Good at starting new activities & $\begin{array}{l}\text { H3. You are good at starting } \\
\text { businesses activities that your } \\
\text { competitors have not started: } 7 \mathrm{pt} \text {. } \\
\text { likert scale ranging from strongly } \\
\text { disagree to strongly agree }\end{array}$ \\
\hline & & Verhees et al. (2012) & $\begin{array}{l}\text { Have knowledge to be the first to } \\
\text { exploit opportunities }\end{array}$ & $\begin{array}{l}\text { H4. You know how to be the first } \\
\text { to exploit opportunities if these } \\
\text { arise: } 7 \text { pt. likert scale ranging from } \\
\text { strongly disagree to strongly agree }\end{array}$ \\
\hline & Market orientation skills & $\begin{array}{l}\text { Alby et al. (2011), Chen et al. } \\
\text { (1998), Edgcomb (2002), } \\
\text { Oosterbeek et al. (2010), Otero- } \\
\text { Neira et al. (2013), Verhees et al. } \\
\text { (2012) }\end{array}$ & Set market shares goals & $\begin{array}{l}\text { I.1 You set market shares } \\
\text { objectives for your business: } 7 \mathrm{pt} . \\
\text { likert scale ranging from strongly } \\
\text { disagree to strongly agree }\end{array}$ \\
\hline
\end{tabular}




\section{Appendix A Constructs and measurements - continued}

\begin{tabular}{|c|c|c|c|c|}
\hline Construct & Operationalisation & Literature & Items/measurements & Questions \\
\hline & & $\begin{array}{l}\text { Alby et al. (2011), Chen et al. } \\
\text { (1998), Edgcomb (2002), } \\
\text { Oosterbeek et al. (2010), Otero- } \\
\text { Neira et al. (2013), Verhees et al. } \\
\text { (2012) }\end{array}$ & Set sales goals & $\begin{array}{l}\text { I.2. You set sales goals for your } \\
\text { business: } 7 \text { pt. likert scale ranging } \\
\text { from strongly disagree to strongly } \\
\text { agree }\end{array}$ \\
\hline & & $\begin{array}{l}\text { Alby et al. (2011), Chen et al. } \\
\text { (1998), Edgcomb (2002), } \\
\text { Oosterbeek et al. (2010), Otero- } \\
\text { Neira et al. (2013), Verhees et al. } \\
\text { (2012) }\end{array}$ & Set profits goals & $\begin{array}{l}\text { I.3. You set your profits goals for } \\
\text { your business: } 7 \text { pt. likert scale } \\
\text { ranging from strongly disagree to } \\
\text { strongly agree }\end{array}$ \\
\hline & & $\begin{array}{l}\text { Alby et al. (2011), Chen et al. } \\
\text { (1998), Edgcomb (2002), } \\
\text { Oosterbeek et al. (2010), Otero- } \\
\text { Neira et al. (2013), Verhees et al. } \\
\text { (2012) }\end{array}$ & $\begin{array}{l}\text { Establish positions in the products } \\
\text { markets }\end{array}$ & $\begin{array}{l}\text { 1.4. You operate in a particular } \\
\text { market niche: } 7 \mathrm{pt} \text {. likert scale } \\
\text { ranging from strongly disagree to } \\
\text { strongly agree }\end{array}$ \\
\hline & & $\begin{array}{l}\text { Alby et al. (2011), Chen et al. } \\
\text { (1998), Edgcomb (2002), } \\
\text { Oosterbeek et al. (2010), Otero- } \\
\text { Neira et al. (2013), Verhees et al. } \\
\text { (2012) }\end{array}$ & Conduct market analyses & $\begin{array}{l}\text { I.5. You conduct market analyses } \\
\text { to improve on your business } \\
\text { strategy: } 7 \text { pt. likert scale ranging } \\
\text { from strongly disagree to strongly } \\
\text { agree }\end{array}$ \\
\hline & & $\begin{array}{l}\text { Alby et al. (2011), Chen et al. } \\
\text { (1998), Edgcomb (2002), } \\
\text { Oosterbeek et al. (2010), Otero- } \\
\text { Neira et al. (2013), Verhees et al. } \\
\text { (2012) }\end{array}$ & Expand business & $\begin{array}{l}\text { 1.6. You expand your business by } \\
\text { opening other branches: } 7 \mathrm{pt} \text {. } \\
\text { likert scale ranging from strongly } \\
\text { disagree to strongly agree }\end{array}$ \\
\hline
\end{tabular}




\section{Appendix A Constructs and measurements - continued}

\begin{tabular}{|c|c|c|c|c|}
\hline Construct & Operationalisation & Literature & Items/measurements & Questions \\
\hline \multirow[t]{5}{*}{ Empowerment outcomes } & Woman empowerment & Karlan \& Valdivia (2011) & Decision making & $\begin{array}{l}\text { J1. You are involved in the decision } \\
\text { making process of your household: } \\
7 \text { pt. likert scale ranging from } \\
\text { strongly disagree to strongly agree }\end{array}$ \\
\hline & & Karlan \& Valdivia (2011) & Family size & $\begin{array}{l}\text { J2. You are involved in deciding } \\
\text { how many children you should } \\
\text { have: } 7 \text { pt. likert scale ranging from } \\
\text { strongly disagree to strongly agree }\end{array}$ \\
\hline & & Karlan \& Valdivia (2011) & $\begin{array}{l}\text { Money to be taken from the } \\
\text { business }\end{array}$ & $\begin{array}{l}\text { J3. You are involved in deciding } \\
\text { how much money should be taken } \\
\text { from the business: } 7 \text { pt. likert scale } \\
\text { ranging from strongly disagree to } \\
\text { strongly agree }\end{array}$ \\
\hline & & Karlan \& Valdivia (2011) & Payment of household bills & $\begin{array}{l}\text { J4. You ensure that household bills } \\
\text { are paid: } 7 \text { pt. likert scale ranging } \\
\text { from strongly disagree to strongly } \\
\text { agree }\end{array}$ \\
\hline & & Karlan \& Valdivia (2011) & Separation of money / income & $\begin{array}{l}\text { J5. It is necessary to separate your } \\
\text { income from that of your spouse: } 7 \\
\text { pt. likert scale ranging from } \\
\text { strongly disagree to strongly agree }\end{array}$ \\
\hline
\end{tabular}


Appendix A Constructs and measurements - continued

\begin{tabular}{|l|l|l|l|l|}
\hline Construct & Operationalisation & Literature & Items/measurements & Questions \\
\hline Child labour & Child labour & Karlan \& Valdivia (2011) & Hours child works & $\begin{array}{l}\text { K1. How many hours does the child } \\
\text { work per day? }\end{array}$ \\
\hline & & Karlan \& Valdivia (2011) & Hours child goes to school & $\begin{array}{l}\text { K2. How many hours does the child } \\
\text { go to school per day? }\end{array}$ \\
\hline
\end{tabular}




\section{Appendix B Training modules}

\begin{tabular}{|c|c|c|}
\hline Modules & Topics & Sub-topics \\
\hline \multirow[t]{3}{*}{ Business operations skills (Day 1 ) } & $\begin{array}{l}\text { General Business } \\
\text { planning }\end{array}$ & Short-term planning \\
\hline & & Budgeting \\
\hline & & Handling security \\
\hline \multirow[t]{6}{*}{ (Day 2) } & Record keeping & Effective book keeping \\
\hline & & Stock taking and inventory \\
\hline & & Effective filing \\
\hline & $\begin{array}{l}\text { Financial } \\
\text { Management }\end{array}$ & Paying yourself a fixed salary \\
\hline & & Calculating profits \\
\hline & & What to check before applying for credit \\
\hline \multirow[t]{6}{*}{ Entrepreneurial skills (Day 3) } & Risk taking & Checklist to consider before risk taking \\
\hline & & Making decisions under pressure \\
\hline & & Taking responsibility for decisions \\
\hline & Innovativeness & How to introduce new products and services \\
\hline & & Identification and entry into a new market \\
\hline & & $\begin{array}{l}\text { Introducing new methods of production } \\
\text { Marketing and management }\end{array}$ \\
\hline \multirow[t]{4}{*}{ (Day 4) } & Pro-activeness & Techniques for starting new businesses \\
\hline & & How to be the first to start business activities \\
\hline & $\begin{array}{l}\text { Interpersonal } \\
\text { Relations }\end{array}$ & Importance of employee rewards \\
\hline & & Importance of employee sanctions \\
\hline
\end{tabular}




\begin{tabular}{|l|l|l|}
\hline & & Importance of employee procedures \\
\hline & Customer Relations & Dealing with angry customers \\
\hline & & Listening to customers \\
\hline & & Understanding the customers' needs \\
\hline & & Perception of customers \\
\hline (Day 5) & & \\
\hline & Market orientation & Setting market share goals \\
\hline & & Setting sales goals \\
\hline & & Setting profits goals \\
\hline & & Establishing a position in the product market \\
\hline & & Conducting a simple market analysis or survey \\
\hline & & How to expand business \\
\hline
\end{tabular}




\section{Summary}

This thesis examines the extent to what corporate social responsibility (CSR) strategies, entrepreneurial and business skills and programmes for training and monitoring improve microbusiness performance and loan repayment rates:

'To what extent do corporate social responsibility strategies, entrepreneurial and business skills and programmes for training and monitoring improve loan repayment rates of microfinance debtors in developing countries?'

MFIs that adopt CSR strategies provide for both financial and social empowerment services. Social empowerment services may include primary health care services, occupational skills training for microfinance debtors and debtor monitoring programmes. The 2008 credit crunch led many MFIs to abandon their CSR strategies. We analyse the case of uniCredit Ghana MFI and argue that CSR strategies contribute to public support for the MFI. This helps raise deposits and improves funding opportunities. Social empowerment investment improve microbusiness performance and loan repayment rates. We expect those MFIs that adopt CSR strategies to improve their sustainability, more than do MFIs that specialize in providing financial services only.

We establish that those microfinance debtors who consider themselves endowed with entrepreneurial and business skills do not repay loans better than those microfinance debtors lacking these skills. Highly educated entrepreneurs do not repay their loans any better relative to those with primary or secondary education only. We establish that business experience is the only constituent of human capital that matters for business performance and loan repayment rates. Experienced microfinance debtors systematically repay their loans better than do those entrepreneurs lacking business experience.

We observe that microfinance debtors do not agree on what skills they think are important for loan repayment probabilities. This result implies that every single microfinance debtor needs to acquire specific skills. Training programmes cannot be standardized and should be tailored towards the needs of the individual microfinance debtor. We establish that MFI loan officers neither agree on the ranking of specific skills they think are important for microfinance debtors to repay their loans promptly. This result suggests that MFI loan officers should be trained to 
better understand the relevance of specific entrepreneurial and business skills for microfinance entrepreneurs.

We empirically establish that training programmes fail to improve loan repayment rates. Programmes for intensive microfinance debtor monitoring significantly improve loan repayment rates. Intensive monitoring is equally effective for highly and poorly educated, experienced and unexperienced, female and male microfinance debtors: MFIs may significantly improve repayment rates should they consistently monitor their microfinance debtors intensively. 


\section{About the author}

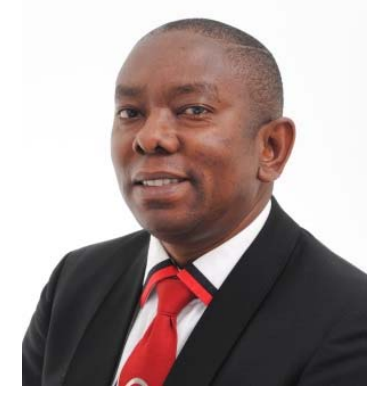

\section{Education}

Daniel Agbeko was born in 1972 in Kumasi, Ghana. He graduated from the University of Cape Coast in 1997 with a BSc in Agriculture, concurrently with a Diploma in Education. In 2004 Daniel had a scholarship to the Netherlands for a short course in Rural Microfinance, later the same year he had another scholarship to India to study microfinance. In 2006 Daniel developed interest in Microfinance so he left Ghana to the University of Leicester in the United Kingdom to pursue an MBA in International Finance with thesis in Microfinance. To climax his ambition in 2012 he won another scholarship to pursue a PhD in Wageningen University of Research on Microfinance and Entrepreneurship.

\section{Profession}

In 1998 Daniel joined Wamfie Rural Bank as a project officer. In 2002 he became Assistant General Manager of Wamfie Rural Bank. In late 2004 Daniel left Wamfie Rural Bank and joined a non-governmental MFI, the women and development project (WADEP) as the managing director. In the later part of 2005, Daniel left for UK to further his education. On completion of his MBA in 2008, he returned immediately to Ghana and he joined uniCredit Ghana Limited as the first Branch Manager of the Ashaiman branch of uniCredit. In 2012 he won a contract in collaboration with Quente.nl to trained uniCredit staff. Also in 2015 he won another contract in collaboration with Quente.nl to train staff of the food research institute in Ghana. Through his interaction with Quente.nl he formed a franchise with Quente.nl which resulted in the establishment of Quente Africa a consulting company specialised in capacity building in the area of microfinance, entrepreneurship, agriculture, research and project management. In 2015 Daniel become an international partner of Quente.nl. In 2016, Quente Africa in collaboration with CINOP Global based in the Netherlands, won a four-year capacity building contract to develop the capacity of the four Agricultural colleges in Ghana under the NICHE-GHA-270 project. In December 2016, Quente Africa won an international contract by 
Oxford Policy Management to link and build the capacity of all 'susu' micro savings clients in Ghana, and link them to Banks using electronic platforms. In January 2016, Daniel Joined the Regent University of Science and Technology as the Director for business development and a senior lecturer. Daniel's passion to help the poor led him to establish the Hands-up Rescue Foundation in 2014, an NGO involved in vocational training such as sewing, beads making, batik tie- and-dye manufacture etc. for poor and needy young adolescence girls, and providing them with sewing machines on graduation and setting them up in business.

\section{Experience}

Daniel has 19 years of practical experience and technical knowledge in rural finance, entrepreneurship and microfinance with strong skills in credit analysis for micro, small and medium scale enterprises. He has been involved in microfinance and entrepreneurship training programmes for the rural banks and other private microfinance institutions across Ghana and other developing countries. He has presented technical papers on microfinance, entrepreneurship and rural banking at several seminars in Ghana and microfinance and entrepreneurship conferences in India, the Netherlands, France, Italy, Norway, the United Kingdom and the United States of America.

\section{Family}

Daniel got married in 2002 to Sussie Agbeko and they are blessed with a daughter, Sybill Agbeko and a son Austin-Paul Agbeko. 


\begin{tabular}{|c|c|c|c|}
\hline Name of activity & Department/ Institute & Year & ECTS* \\
\hline \multicolumn{4}{|l|}{ A. Project related competencies } \\
\hline $\begin{array}{l}\text { Micro finance and marketing in developing } \\
\text { countries, DEC } 51806\end{array}$ & Wageningen University & 2013 & 6.0 \\
\hline $\begin{array}{l}\text { Qualitative data analysis: Procedures and } \\
\text { strategy, YRM } 60806\end{array}$ & Wageningen University & 2012 & 6.0 \\
\hline Research proposal writing & WUR & 2013 & 6.0 \\
\hline $\begin{array}{l}\text { 'Identifying the entrepreneurial competence of } \\
\text { micro clients in MFI's: A case study of } \\
\text { uniCredit Ghana Limited' }\end{array}$ & WICaNeM conference & 2014 & 1.0 \\
\hline $\begin{array}{l}\text { 'Corporate social responsibility strategies } \\
\text { adopted by microfinance institutions in an era } \\
\text { of economic crisis' }\end{array}$ & $\begin{array}{l}\text { Management of uniCredit } \\
\text { Ghana Ltd }\end{array}$ & 2013 & 1.0 \\
\hline $\begin{array}{l}\text { 'Entrepreneurial competencies and loan } \\
\text { repayment of microfinance clients' }\end{array}$ & $\begin{array}{l}7^{\text {th }} \text { African Business and } \\
\text { Entrepreneurship } \\
\text { conference }\end{array}$ & 2016 & 1.0 \\
\hline $\begin{array}{l}\text { 'The impact of entrepreneurial training and } \\
\text { monitoring on loan repayment performance of } \\
\text { clients at the base of the pyramid: a case } \\
\text { study on uniCredit Ghana' }\end{array}$ & $\begin{array}{l}2^{\text {nd }} \text { Microfinance and } \\
\text { Rural Finance } \\
\text { Conference }\end{array}$ & 2016 & 1.0 \\
\hline \multicolumn{4}{|l|}{ B. General research related competencies } \\
\hline WASS Introduction course & WASS & 2012 & 1.0 \\
\hline $\begin{array}{l}\text { Information literacy including EndNote } \\
\text { introduction (ILP) }\end{array}$ & WGS & 2012 & 1.0 \\
\hline $\begin{array}{l}\text { Techniques writing and presenting scientific } \\
\text { papers }\end{array}$ & WGS & 2013 & 1.2 \\
\hline Scientific writing & WGS & 2012 & 1.8 \\
\hline \multicolumn{4}{|c|}{ C. Career related competencies/Personal developments } \\
\hline $\begin{array}{l}\text { Research Methodology: From topic to } \\
\text { proposal }\end{array}$ & WASS & 2012 & 4.0 \\
\hline Writing Grant proposal & WGS & $2015 / 2016$ & 2.0 \\
\hline Entrepreneurship in and outside Science & WGS & 2016 & 1.4 \\
\hline Total & & & 34.4 \\
\hline
\end{tabular}

*One credit according to ECTS is on average equivalent to 28 hours of study load 


\section{Funding}

The research described in this thesis as well as printing and other associated costs was financially supported by the Nuffic Netherlands Fellowship Program. 